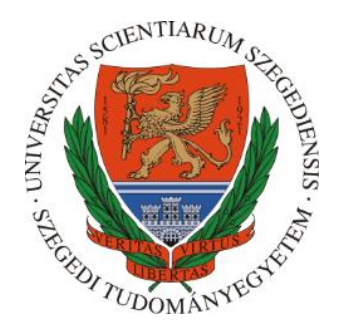

\title{
Current issues in breast surgery
}

\author{
$\mathrm{Ph}$. D. Thesis
}

\section{Róbert Maráz, M.D.}

\author{
Supervisor: \\ Prof. Gábor Cserni, M.D., Ph.D., D.Sc. Department of Pathology, Bács-Kiskun County \\ Teaching Hospital, Kecskemét \& \\ Department of Pathology, University of Szeged
}

Department of Surgery and Oncology, Bács-Kiskun County Teaching Hospital, Kecskemét

Szeged

2015.

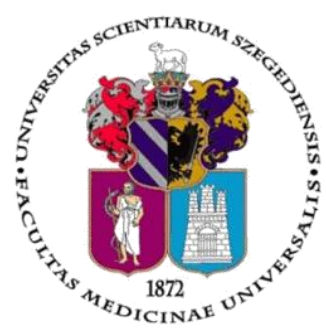




\section{LIST OF FULL PAPERS THAT SERVED AS THE BASIS OF THE PH.D. THESIS}

I. Maráz R, Boross G, Ambrózay E, Svébis M, Cserni G.

Selective ductectomy for the diagnosis and treatment of intraductal papillary lesions presenting with single duct discharge.

Pathol Oncol Res 2013; 19 (3): 589-595.

IF: 1.806

II. Maráz R, Boross G, Pap-Szekeres J, Rajtár M, Ambrózay E, Cserni G.

Internal Mammary Sentinel Node Biopsy in Breast Cancer. Is it indicated?

Pathol Oncol Res 2014; 20 (1): 169-177.

IF: 1.806

III. Maráz R, Boross G, Pap-Szekeres J, Markó L, Rajtár M, Ambrózay É, Bori R, Cserni G.

The role of sentinel node biopsy in male breast cancer.

Breast Cancer DOI: 10.1007/s12282-014-0535-1 Epub 2014.May 3

IF: $\mathbf{1 , 5 0 5}$

IV. Cserni G, Maráz R.

Regional disease control in selected patients with sentinel lymph node involvement and omission of axillary lymph node dissection.

Pathol Oncol Res DOI: 10.1007/s12253-015-9899-6 Epub 2015. Febr 9

IF: 1.806 


\section{OTHER PUBLICATIONS}

\section{ARTICLES}

I. Pap Szekeres J, Lóránd P, Maráz R.

Nőgyógyászati mütétek során nyert tapasztalataink az akut betegellátásban (1984-1993).

Magyar Sebészet 1996; 49: 11-15.

II. Maráz R, Boross G, Cserni G, Baltás B.

Gyermekkori mesenterialis lymphangioma cavernosum sikerrel operált esete.

Magyar Sebészet 1999; 52: 300-302.

III. Maráz R, Cserényi L, Baltás B.

Vena axillaris kompresszió sikerrel operált esete.

Magyar Sebészet 1997; 50: 389-391.

IV. Maráz R, Boross G.

A belső sérvekről osztályunk 15 éves anyaga kapcsán (1984-1998).

Magyar Sebészet 1999; 52: 283-287.

V. Cserni G, Burzykowski T, Vinh-Hung V, Kocsis L, Boross G, Sinkó M, Tarján M, Bori R, Rajtár M, Tekle E, Maráz R, Baltás B, Svébis M.

Axillary sentinel node and tumor-related factors associated with non-sentinel node involvement in breast cancer.

Jpn J Clin Oncol 2004; 34: 519-524.

IF: $\mathbf{0 , 7 8 6}$

V. Kocsis L, Svébis M, Boross G, Sinkó M, Maráz R, Rajtár M, Cserni G.

Use and limitations of a nomogram predicting the likelihood of non-sentinel node involvement after a positive sentinel node biopsy in breast cancer patients.

Am Surg 2004; 70: 1019-1024.

\section{IF: $\mathbf{1 , 1 5 8}$}

VI. Maráz R, Boross G, Svébis M, Gyánti R, Vízhányó R, Markó L, Hajnal L, Szűcs M, Ambrózay É, Lőrincz M.

A neoadjuváns, avagy primer szisztémás kemoterápia eredményei és az ezt követő emlőmegtartó mütétek aránya a lokoregionálisan elörehaladott emlőrákos betegeknél.

Magyar Sebészet 2005; 5: 225-232.

VII. Cserni G, Boross G, Maráz R, Rajtár M, Ambrózay É, Bori R, Sinkó M, Svébis M.

Örszemnyirokcsomó-biopszia in situ emlörákban. A Bács-Kiskun Megyei Önkormányzat

Kórházának tapasztalatai és irodalmi összefoglalás.

Magyar Sebészet 2006; 59: 164-172. 
VIII. Coufal O, Pavlík T, Fabian P, Bori R, Boross G, Sejben I, Maráz R, Koca J, Krejcí E, Horáková I, Foltinová V, Vrtelová P, Chrenko V, Eliza Tekle W, Rajtár M, Svébis M, Fait V, Cserni G.

Predicting non-sentinel lymph node status after positive sentinel biopsy in breast cancer: what model performs the best in a Czech population?

Pathol Oncol Res 2009; 15:733-740.

\section{IF: 1,152}

IX. Cserni G, Bori R, Sejben I, Boross G, Maráz R, Svébis M, Rajtár M, Tekle Wolde E, Ambrózay É.

A hónalji nyirokcsomók további érintettségére vonatkozó modellek elemzése kisméretü ( $\leq 15 \mathrm{~mm}$ ) őrszemnyirokcsomó-áttétes emlörákokban. Markusovszky Lajos-díi Orvosi Hetilap 2009; 150: 2182-2188.

X. Maráz R.

Sebészeti vonatkozások: 11 International St Gallen Conference. Primary therapy of early breast cancer.

Údonságok az onkológiában 2009.szeptember I évf.2. szám

XI. Lázár Gy, Besznyák I, Boross G, Farsang Z, Gulyás G, Jakab F, Maráz R. Az emlőrák korszerü sebészi kezelése. II. Konszenzuskonferencia

Magyar Sebészet 2010; 3:132-140.

XII. Lázár Gy, Besznyák I, Boross G, Farsang Z, Gulyás G, Jakab F, Maráz R. A 2. Emlőrák Konszenzus Konferencia szakmai ajánlásai.

Az emlörák korszerü sebészi kezelése.

Magyar Onkológia 2010; 54: 106-114.

XIII. Maráz R.

LHRH-analóg-goszerelinkezelés fiatalkorban. Hosszú túlélés, jó életminőség.

Lege Artis Medicinae 2012; 22: 455-459.

XIV. Cserni G, Boross G, Maráz R, Leidenius MH, Meretoja TJ, Heikkila PS, Regitnig P, Luschin-Ebengreuth G, Zgajnar J, Perhavec A, Gazic B, Lázár G, Takács T, Vörös A, Audisio RA.

Multicentre validation of different predictive tools of non-sentinel lymph node involvement in breast cancer.

Surg Oncol 2012; 21:59-65.

\section{IF: 2.136}

XV. Cserni G, Bori R, Maráz R, Leidenius MH, Meretoja TJ, Heikkila PS, Regitnig P, LuschinEbengreuth G, Zgajnar J, Perhavec A, Gazic B, Lázár G, Takács T, Vörös A, Audisio RA.

Multi-institutional comparison of non-sentinel lymph node predictive tools in breast cancer patients with high predicted risk of further axillary metastasis.

Pathol Oncol Res 2013; 19: 95-101.

\section{IF: 1.806}




\section{ABSTRACTS}

I. Maráz R, Boross G, Baltás B.

A belső sérvekről osztályunk 15 éves anyaga kapcsán.

Magyar Sebészet 1998; 51: 142.

II. Maráz R, Cserni G, Boross G, Markó L, Hajnal L, Szücs M.

Neodjuvant chemotherapy with CEF (cyclophosphamide, epirubicin, 5-fluorouracil) and 3M (mitoxantron, methotrexate, mitomycin-c).

The Breast Journal 2001; 7: 68.

III. Maráz R, Markó L, Hajnal L, Boross G, Cserni G, Szücs M.

A neoadjuváns kemoterápia eredményei a lokálisan elörehaladott emlőrákos betegeknél a Kecskeméti Onkoradiológiai Központban.

Magyar Onkológia 2001; 45: 282.

IV. Maráz R. , Boross G, Svébis M, Markó L, Hajnal L, Ambrózay É, Cserni G.

A neoadjuváns kemoterápia eredményei és az ezt követő emlőmegtartó mütétek aránya a lokálisan előrehaladott emlőrákos betegeknél a Kecskeméti Megyei Kórházban.

Magyar Sebészet 2002; 55: 158.

V. Maráz R, Boross G, Svébis M, Markó L, Hajnal L, Szűcs M, Amrózay É, Lőrinc M, Cserni G.

A neoadjuváns kemoterápiát követő emlömegtartó mütétekről a sebész szemszögéből.

Magyar Onkológia 2003; 47: 283.

VI. Maráz R, Boross G, Svébis M, Markó L, Hajnal L, Szűcs M, Amrózay É, Lőrinc M, Cserni G.

A neoadjuváns kemoterápiát követő emlömegtartó mütétekről a sebész szemszögéböl.

Magyar Sebészet 2004; 57: 128.

VII. Maráz R, Boross G, Svébis M, Markó L, Szűcs M, Amrózay É, Lőrinc M, Rajtár M, Sinkó M, Cserni G.

Az intraoperatív ultrahang szerepe a nem tapintható emlődaganatok sebészetében.

Magyar Onkológia 2005; 49: 51.

VIII. Maráz R, Boross G, Svébis M, Markó L, Szűcs M, Amrózay É, Lőrinc M, Rajtár M, Sinkó M, Cserni G.

Az intraoperatív ultrahang szerepe a nem tapintható emlődaganatok sebészetében.

Magyar Onkológia 2007; 51: 360.

IX. Maráz R, Boross G, Füstös L, Svébis M, Ambrózay É, Lőrincz Margit, Cserni G.

Az intraductalis papillomák mütéte során felmerülő kérdésekröl.

Magyar Onkológia 2007; 51: 360.

X. Maráz R, Boross G, Svébis M, Markó L, Szűcs M, Ambrózay É, Lőrincz M, Rajtár M, Sinkó M, Cserni G.

Az axilla komplex kezelésének változása az elmúlt 10 év során.

Magyar Sebészet 2008; 61:173. 
XI. Maráz R, Cserni G, Pajkos G, Boross G, Svébis M.

Az axilla komplex kezelésének változása az elmúlt 10 év során, különös tekintettel az őrszem nyirokcsomó mikrometasztázisának terápiájára.

Orvostovábbképző Szemle 2008; november különszám: 9.

XII. Maráz R, Boross G, Svébis M, Pajkos G, Vízhányó R, Hajnal L, Markó L, Ambrózay É.

A sebészeti és onkológiai kezelés dilemmái neoadjuváns kemoterápiás kezelést követően lokoregionálisan elörehaladott emlörákos betegeknél.

Magyar Onkológia 2009; 53: 75.

XIV. Maráz R, Boross G, Svébis M, Vízhányó R, Pajkos G, Ambrózay É.

A sebész döntésének jelentősége az emlörákos betegek komplex kezelésében.

Magyar Sebészet 2010; 63: 212.

XV. Maráz R.

Az ARIADNÉ vizsgálat eredményei.

(szponzorált előadás kivonata)

Orvostovábbképzö Szemle 2012; november különszám: 21.

XVI. Maráz R, Boross G, Pap-Szekeres J, Markó L, Cserni G.

A mammaria interna őrszemnyirokcsomó-biopsziával nyert tapasztalataink.

Magyar Onkológia 2013; 57: 59.

XVII. Maráz R, Pap-Szekeres J, Boross G, Svébis M, Rácz A, Cserni G.

A mammaria interna örszemnyirokcsomó-biopsziával nyert tapasztalataink.

Magyar Sebészet 2014; 67: 184.

XVIII. Maráz R, Cserni G.

Minimális őrszemnyirokcsomó érintettség axillaris blokkdisszekció nélkül - 111 emlőrákos beteg követéses vizsgálata.

Klinikai Onkológia 2014;1:1.különszám 29. 


\section{FIRST AUTHORED PRESENTATIONS:}

1. Maráz R, Boross G.

Belső sérv kizáródása okozta ileus osztályunk 10 éves anyagában.

Fiatal Sebészek Fóruma Esztergom, 1994.október 08.

2. Maráz R, Boross G.

Belső sérvek elöfordulása osztályunk tíz éves anyagában.

Kecskemét Fiatalok Előadói Fóruma Kecskemét, 1995.június 29.

3. Maráz R, Boross G, Cserni G, Kocsis L.

Rare case of malignant mesenchymal tumor of the breast.

Fiatal Sebészek Angol Nyelvü Kazuisztikai Fóruma Budapest, 1996.április 19.

4. Maráz R, Cserényi L, Raskó E.

Rupturált hasi aorta aneurysmák előfordulása és kezelése osztályunk 5 éves anyagában.

Fiatal Sebészek Fóruma Miskolc, 1997.április 18.

5. Maráz R, Bikk A.

Vena axillaris kompresszió sikerrel operált esete.

Bács-Kiskun Megyei Fiatal Orvosok Fóruma Kecskemét,1997. november 14.

6. Maráz R, Bikk A.

Successful operation of an axillary vein compression.

Fiatal Sebészek Angol Nyelvü Kazuisztikai Fóruma Budapest, 1997. november 21.

7. Maráz R, Boross G, Baltás B.

A belső sérvekröl osztályunk 15 éves anyaga kapcsán.

Magyar Sebész Társaság 54. Kongresszusa Budapest, 1998.június 15-17.

8. Maráz R, Vajda K, Kovács K, Raskó E, Baltás B.

Endokrin sebészeti tevékenységünk értékelése.

Bács-Kiskun Megyei Orvos- Gyógyszerész Napok Kecskemét, 1998. október 15.

9. Maráz R, Boross G, Cserni G.

Rare case of acute abdomen in childhood.

Fiatal Sebészek Angol Nyelvü Kazuisztikai Fóruma Szeged, 1998. november 28.

10. Maráz R, Boross G, Cserni G, Fekete L, Ambrózay É, Rajtár M.

Hogyan befolyásolja a diagnosztikus lehetőségek fejlődése az emlőrák sebészetét?

Az emlörák aktuális kérdései Szenológiai Konferencia Kecskemét, 1999.szeptember 30.

11. Maráz R, Boross G, Cserni G.

Gyermekkori mesenterialis lymphangioma cavernosum sikerrel operált esete.

Bács-Kiskun Megyei Fiatal Orvosok Fóruma Kecskemét, 1999. október 29. 
12. Maráz R, Boross G, Cserni G.

The complex treatment of a patient with advanced breast cancer.

Fiatal Sebészek Angol Nyelvű Kazuisztikai Fóruma Debrecen, 2001. április 28.

13. Maráz R.

Neoadjuváns kemoterápiában részesült, lokálisan elörehaladott emlörákos betegek kezelésének múltja jelene és jövője a kecskeméti Onkoradiológiai Központban.

Az onkológiai betegek ellátásának mai gyakorlata és kívánalmai a Dél-Dunántúlon Pécs, 2001.május 09-11.

14. Maráz R, Cserni G, Boross G, Markó, Hajnal L, Szücs M.

Neoadjuvant chemotherapy with CEF (cyclophosphamide, epirubicin, 5-fluorouracil) and 3M (mitoxantron, methotrexate, mitomycin-c).

1st Congress of the World Society for Breast Health (WSBH) Turkey Istanbul, 2001. szeptember 23-26.

(poster)

15. Maráz R, Oláh Cs.

Új utak a sérvsebészetben.

Bács-Kiskun Megyei Orvos- Gyógyszerész Napok Baja, 2001. október 11.

16. Maráz R.

A neoadjuváns kemoterápia eredményei és az ezt követő emlőmegtartó mütétek aránya a lokálisan elörehaladott emlörákos betegeknél a kecskeméti megyei kórházban.

Fiatal Sebészek Fóruma Szeged, 2001. november 16-17.

17. Maráz R, Cserni G, Boross G, Markó L, Hajnal L, Szücs M.

A neoadjuváns kemoterápia eredményei és az ezt követő emlőmegtartó mütétek aránya a lokálisan előrehaladott emlőrákos betegeknél a kecskeméti megyei kórházban.

Magyar Onkológusok Társaságának 24. Kongresszusa Budapest, 2001. november 22-24.

18. Maráz R, Boross G, Cserni G, Svébis M, Ambrózay É, Hajnal L.

A neoadjuváns kemoterápia eredményei és az ezt követő emlőmegtartó mütétek aránya a lokálisan előrehaladott emlőrákos betegeknél a kecskeméti megyei kórházban.

Magyar Sebész Társaság 56. Kongresszusa Budapest, 2002. június 12-14.

19. Maráz R, Boross G, Cserni G, Svébis M, Ambrózay É, Hajnal L.

A neoadjuváns kemoterápia eredményei és az ezt követő emlőmegtartó mütétek aránya a lokálisan előrehaladott emlőrákos betegeknél a kecskeméti megyei kórházban.

Magyar Onkológusok Társaságának Tudományos Konferenciája

Kecskemét, 2002. október 4-5.

20. Maráz R, Cserni G, Boross G, Markó L, Hajnal L, Szücs M.

A neoadjuváns kemoterápia eredményei és az ezt követő emlőmegtartó mütétek aránya a lokálisan előrehaladott emlőrákos betegeknél a kecskeméti megyei kórházban.

Bács-Kiskun Megyei Fiatal Egészségügyi Dolgozók Tudományos Fóruma

Kecskemét, 2002. október 10-18. 
21. Maráz R, Boross G, Cserni G, Svébis M, Ambrózay É, Hajnal L.

A neoadjuváns kemoterápia eredményei és az ezt követő emlőmegtartó mütétek aránya a lokálisan előrehaladott emlőrákos betegeknél a kecskeméti megyei kórházban.

Magyar Klinikai Onkológiai Társaság II. Kongresszusa Budapest, 2002. november 22.

22. Maráz R, Cserni G, Boross G, Markó L, Hajnal L, Szücs M.

Response rates following neoadjuvant chemotherapy and breast-conserving treatment to patients with locally advanced breast cancer.

2nd Congress of the World Society for Breast Health (WSBH) Budapest, 2003. június 19-24.

23. Maráz R, Cserni G, Boross G, Markó L, Hajnal L, Szücs M.

Neoadjuváns kemoterápiát követő emlőmegtartó mütétekről a sebész szemszögéből.

Magyar Onkológusok Társaságának XXV. Kongresszusa Szeged, 2003. november 12-15.

24. Maráz R, Cserni G, Boross G, Markó L, Hajnal L, Szűcs M.

Neoadjuváns kemoterápia eredményei lokálisan előrehaladott emlőrákok kezelésében.

Fiatal Onkológusok és Fiatal Sebészek Fóruma Kecskemét, 2004. április 16-17.

25. Maráz R, Cserni G, Boross G, Markó L, Hajnal L, Szücs M.

Neoadjuváns kemoterápiát követő emlömegtartó mütétekről a sebész szemszögéből.

Magyar Sebész Társaság 57. Kongresszusa Pécs, 2004. június 17.

26. Maráz R.

A nem tapintható emlődaganatok sebészete.

A szervezett lakossági emlőszürés tapasztalatai Bács-Kiskun Megyében.

A népegészségügyi program tavaszi rendezvényei, Kecskemét, 2005. április 01.

27. Maráz R, Cserni G, Boross G, Markó L, Hajnal L, Szücs M.

Az intraoperatív ultrahang szerepe a nem tapintható emlődaganatok sebészetében.

I.Szegedi Emlőrák Szimpózium Szeged, 2005. szeptember 16-18.

28. Maráz R, Cserni G, Boross G, Markó L, Hajnal L, Szűcs M, Ambrózay É.

A nem tapintható emlődaganatok sebészetéről.

A Magyar Sebész Társaság Dél-Magyarországi Csoportja és a SZAB Orvostudományi Szakbizottság Klinikai és Kísérletes Sebészeti Munkacsoportjának Kongresszusa Kecskemét, 2005. október 08 .

29. Maráz R, Cserni G, Boross G, Markó L, Hajnal L, Szűcs M, Ambrózay É.

Az intraoperatív ultrahang szerepe a nem tapintható emlődaganatok sebészetében.

Magyar Onkológusok Társaságának XXVI. Kongresszusa Budapest, 2005. november 10-12.

30. Maráz R.

A decubitus korszerü kezelése.

(felkért előadás)

Sebinko Szövetség 10. Jubileumi Kongresszusa 2006. október 26-27.

Tatabánya, 2006. október 26-27. 
31. Maráz R, Boross G, Svébis M, Vízhányó R, Hajnal L, Markó L, Szűcs M, Ambrózay É, Lörincz M.

A sebészi kezelés dilemmái neoadjuváns kemoterápiás kezelést követően lokoregionálisan elörehaladott emlőrákos betegeknél.

Magyar Sebész Társaság 58. Kongresszusa Budapest, 2006. szeptember 6-9.

32. Maráz R, Svébis M, Középesy L, Jakab G, Szücs M.

A rectum tumorok neoadjuváns radiokemoterápiás kezelése.

Coloproctológiai Kongresszus Debrecen, 2007. március 22-24.

33. Maráz R.

A korszerü LMWH kezelés elméleti és gyakorlati kérdései.

Fiatal Onkológusok és Fiatal Sebészek Fóruma Kecskemét, 2007. április 26-27.

34. Maráz R, Cserni G, Boross G, Markó L, Hajnal L, Szücs M, Ambrózay É.

Az intraoperatív ultrahang szerepe a nem tapintható emlődaganatok sebészetében.

Magyar Onkológusok Társaságának Kongresszusa Budapest, 2007. november 8-10.

35. Maráz R, Boross $\mathrm{G}$, Füstös L, Svébis $\mathrm{M}$, Ambrózay É, Lőrincz $\mathrm{M}$, Cserni G. Az intraductalis papillomák mütéte során felmerülő kérdésekről. II. Szegedi Emlőrák Szimpózium Szeged, 2007. augusztus 31- szeptember 2.

36. Maráz R.

A nem tapintható emlődaganatok sebészete.

IASGO Magyar Tagozat Kongresszusa Eger, 2008. május16-17.

37. Maráz R, Svébis M.

Thromboprophylaxis az onkológiai sebészetben.

IASGO Magyar Tagozat Kongresszusa Eger, 2008. május 16-17.

38. Maráz R, Boross G, Svébis M, Markó L, Szűcs M, Ambrózay É, Lőrincz M, Rajtár M, Sinkó M, Cserni G.

Az intraoperatív ultrahang szerepe a nem tapintható emlödaganatok sebészetében.

Magyar Sebész Társaság 59. Kongresszusa Debrecen, 2008. június 18.

39. Maráz R, Boross G, Svébis M, Markó L, Szűcs M, Ambrózay É, Lőrincz M, Rajtár M, Sinkó M, Cserni G.

Az intraductalis papillomák mütéte során felmerülő kérdésekről.

Magyar Sebész Társaság 59. Kongresszusa Debrecen, 2008. június 18.

40. Maráz R, Cserni G, Pajkos G, Boross G, Svébis M.

Az axilla komplex kezelésének változása az elmúlt 10 év során, különös tekintettel az őrszemnyirokcsomó micrometastasisának terápiájára.

Magyar Klinikai Onkológiai Társaság Kongresszusa Budapest, 2008. november 6-8.

41. Maráz R, Boross G, Svébis M, Pajkos G, Vízhányó R, Hajnal L, Markó L, Ambrózay É.

A sebészeti és onkológiai kezelés dilemmái neoadjuváns kemoterápiás kezelést követően lokoregionálisan előrehaladott emlőrákos betegeknél.Az elmúlt tíz év eredményei.

III. Szegedi Emlőrák Szimpózium Szeged, 2009. szeptember 17-19. 
42. Maráz R, Boross G, Svébis M, Vízhányó R, Pajkos G, Ambrózay É.

A sebész döntésének jelentősége az emlörákos betegek komplex kezelésében.

Magyar Sebész Társaság 60. Kongresszusa Siófok, 2010. szeptember 8-11.

43. Maráz R, Pap-Szekeres J, Svébis M, Füstös L.

Gyomordaganat miatt végzett laparoscopos mütéteink.

Bács-Kiskun Megyei Önkormányzat Kórháza Kecskemét, Általános Sebészet

Magyar Sebész Társaság 60. Kongresszusa Siófok, 2010. szeptember 8-11.

44. Maráz R, Cserni G, Boross G, Svébis M, Pajkos G.

Pozitív örszemnyirokcsomó és szisztémás kezelés: elhagyható axillaris blockdissectio?

Magyar Klinikai Onkológiai Társaság VI.kongresszusa Budapest, 2010. november 11-13.

45. Maráz R.

Az őrszemnyirokcsomó biopszia hatása a lymphoedema előfordulásának gyakoriságára. (felkért elöadás)

A Magyar Szenológiai Társaság és a Magyar Reumatológusok Egyesülete Közös Tudományos Fóruma Tapolca, 2011. május 06-07.

46. Maráz R.

BRCA génmutációt hordozó emlőrákok diagnosztikai és terápiás sajátosságai Sebészeti vonatkozások.

(felkért előadás)

IV. Szegedi Emlörák Szimpózium Szeged 2011. 09. 16-18.

47. Maráz R, Pajkos G, Vízhányó R, Cserni G, Svébis M.

Szinkron, duplex, ipszilateralis, eltérő immunfenotípussal rendelkező emlőrák kezelése.

IV. Szegedi Emlörák Szimpózium Szeged, 2011. szeptember 16-18.

48. Maráz R.

Metasztatikus emlőrák hosszú távú kezelése fulvesztranttal.

(felkért előadás)

Magyar Onkológusok Társasága XXIX. Kongresszusa Budapest, 2011. november 10-12.

49. Maráz R, Boross G, Svébis M, Vízhányó R, Hajnal L, Markó L, Pajkos G, Ambrózay É, Cserni G.

Változások a sebészeti kezelésben neoadjuváns kemoterápiás kezelést követően lokoregionálisan előrehaladott emlőrákos betegeknél. Az elmúlt 12 év tapasztalatai.

Magyar Sebész Társaság 61. Kongresszusa Szeged, 2012. szeptember 13-15.

50. Maráz R.

Az ARIADNÉ vizsgálat eredményei.

(felkért elöadás)

Magyar Klinikai Onkológiai Társaság VII. Kongresszusa Budapest, 2012. november 8-10. 


\section{Maráz R.}

Akut hasi fájdalom az onkológus- sebész szemével.

(felkért előadás)

Magyar Belgyógyász Társaság Dél-magyarországi Decentrum 44. Tudományos Ülés és Továbbképzés Kiskunhalas, 2013. április 25-27.

52. Maráz R, Boross G.

Változások az emlő sebészetben.

(felkért előadás)

A Magyar Szenológiai Társaság Tudományos Fóruma Kecskemét, 2013. május 17-18.

53. Maráz R.

Profilaktikus emlősebészet.

(felkért előadás)

A Magyar Szenológiai Társaság Tudományos Fóruma Kecskemét, 2013. május 17-18.

54. Maráz R.

Metasztatikus emlőrák kezelése: fulvesztrant-terápia szerepe progresszió esetén.

(felkért előadás)

A Magyar Szenológiai Társaság Tudományos Fóruma Kecskemét, 2013. május 17-18.

55. Maráz R, Fekete L, Boross G, Svébis M, Pap-Szekeres J.

Kivizsgálási-és kezelési algoritmusunk malignus emlődaganatok kezelésénél.

(felkért előadás)

Magyar Nőorvos Társaság Dél-Magyarországi szekciójának XXXIV. Kongresszusa Kecskemét, 2013. október 4-5.

56. Maráz R.

Izolált tumor sejt, mikro- vagy makrometasztázis az őrszemnyirokcsomóban.

(felkért előadás)

Országos Onkológiai Intézet OFTEX továbbképzés Budapest, 2013.október 02.

II. Az őrszemnyirokcsomó biopszia emlőrákban és melanóma malignumban.

57. Maráz R, Boross G, Pap-Szekeres J, Markó L, Cserni G.

A mammaria interna örszemnyirokcsomó-biopsziával nyert tapasztalataink. (poszter előadás)

Magyar Onkológusok Társasága XXX. Kongresszusa Pécs, 2013. november 14-16.

Poszter Díj

58. Maráz R, Pap-Szekeres J, Boross G, Svébis M, Ambrózay É, Markó L, Pajkos G, Cserni G.

A neoadjuváns kemoterápiás kezelés radiológia, sebészeti és onkológiai vonatkozásai. Az elmúlt 14 év tapasztalatai.

(felkért előadás).

A Magyar Szenológiai Társaság Tudományos Tudományos Fóruma Kecskemét, 2014. május 23-24. 
59. Maráz R, Boross G, Rácz A, Pap-Szekeres J, Svébis M.

A rosszindulatú emlö daganatok sebészi kezelése osztályunkon-őrszemnyirokcsomó meghatározás jelentősége a multimodális kezelés kialakításában.

Sebészeti Tudományos Ülés és Kardos Géza Emlékelőadás Lillafüred, 2014 május 30-31.

60. Maráz R, Pap-Szekeres J, Boross G, Svébis M, Ambrózay É, Markó L, Pajkos G, Cserni G.

A neoadjuváns kemoterápiás kezelés radiológia, sebészeti és onkológiai vonatkozásai. Az elmúlt 14 év tapasztalatai.

Magyar Sebész Társaság 2014. évi Kongresszusa Győr, 2014. június 12-14.

61. Maráz R, Pap-Szekeres J, Boross G, Svébis M, Rácz A, Cserni G.

A mammaria interna örszemnyirokcsomó-biopsziával nyert tapasztalataink.

Magyar Sebész Társaság 2014. évi Kongresszusa Győr, 2014. június 12-14.

62. Maráz R.

A neoadjuváns kemoterápiás kezelés sajátosságai.

(felkért előadás)

Az emlőrák korszerü kezelése Cegléd II. Tudományos Este Cegléd, 2014. szeptember 19.

63. Maráz R, Cserni G.

Minimális őrszemnyirokcsomó érintettség axillaris blokkdisszekció nélkül - 111 emlörákos beteg követéses vizsgálata.

Magyar Klinikai Onkológiai Társaság VIII.kongresszusa Budapest, 2014. november 13-15.

64. Maráz R.

A primer szisztémás kezelés sebészeti vonatkozásai.

(felkért előadás)

A Magyar Szenológiai Társaság tudományos ülése Budapest, 2014. december 5.

65. Maráz R.

Emlőrekonstrukció a mindennapi gyakorlatban Kecskeméten

(felkért előadás)

Onkoplasztikus emlősebészet a gyakorlatban Akkreditált továbbképző tanfolyam

Országos Onkológiai Intézet Budapest, 2015. április 1. 


\section{TABLE OF CONTENTS}

LIST OF ABBREVIATIONS 1 .

LIST OF FIGURES 4.

LIST OF TABLES 4.

1. INTRODUCTION 5 .

2. AIMS 9.

3. PATIENTS AND METHODS 10.

3.1 Selective ductectomy for the diagnosis and treatment of intraductal papillary lesions presenting with single duct discharge. 10.

3.2 Internal nammary sentinel lymph node biopsy in breast cancer. Is it indicated? 14 .

3.3 The role of sentinel node biopsy in male breast cancer 17.

3.4 Regional disease control in selected patients with sentinel lymph node involvement and omission of axillary lymph node dissection. 18.

\section{RESULTS 19.}

4.1 Selective ductectomy for the diagnosis and treatment of intraductal papillary lesions presenting with single duct discharge.

4.2 Internal mammary sentinel lymph node biopsy in breast cancer. Is it indicated? 23 .

4.3 The role of sentinel node biopsy in male breast cancer. 26.

4.4 Regional disease control in selected patients with sentinel lymph node involvement and omission of axillary lymph node dissection. 31 .

5. DISCUSSION 36 .

5.1 Selective ductectomy for the diagnosis and treatment of intraductal papillary lesions presenting with single duct discharge.

5.2 Internal mammary sentinel lymph node biopsy in breast cancer. Is it indicated?

5.3 The role of sentinel node biopsy in male breast cancer.

5.4 Regional disease control in selected patients with sentinel lymph node involvement and omission of axillary lymph node dissection.

6. CONCLUSIONS 51 .

7. ACKNOWLEDGEMENTS 52.

8. REFERENCES 53.

9. APPENDIX 59. 


\section{LIST OF ABBREVIATIONS}

$\mathrm{ADH} \quad$ atypical ductal hyperplasia

ALND axillary lymph node dissection

AP atypical papilloma

A-SLN axillary sentinel lymph node

A-SLNB axillary sentinel lymph node biopsy

AXUS axillary ultrasound

BCS breast conserving surgery

BCSS breast cancer specific survival

CC craniocauldal

CCA columnar cell alterations

CI confidence interval

$\mathrm{cm} \quad$ centimeter

CNB core needle biopsy

ChT chemotherapy

D-ALND delayed completion axillary lymph node dissection

DCIS ductal carcinoma in situ

DFS disease free survival

DOD dead of disease

DOOC death of other (unrelated) causes

ER estrogen receptor

FDS fiberoptic ductoscopy

Fig figure

FNA fine needle aspiration

FNAC fine needle aspiration cytology

HER-2 human epidermal growth factor receptor 2

HG high grade

HT hormonal therapy

I-ALND immediate completion axillary lymph node dissection

IDC invasive ductal carcinoma (no special type)

IG intermediate grade

IHC immunohistochemistry

ILC invasive lobular carcinoma 


\begin{tabular}{|c|c|}
\hline IM & internal mammary \\
\hline IMC & internal mammary chain \\
\hline IMC-LND & internal mammary chain lymph node dissection \\
\hline IM-MS & internal mammary and medial supraclavicular \\
\hline IM-SLN & internal mammary sentinel lymph node \\
\hline IM-SLNB & internal mammary sentinel lymph node biopsy \\
\hline IP & intraductal papilloma \\
\hline ITC & isolated tumor cells \\
\hline LFU & last follow up \\
\hline LG & low grade \\
\hline $\mathrm{LN}$ & lobular intraepithelial neoplasia \\
\hline LVI & lymphovascular invasion \\
\hline MAC & macrometastasis \\
\hline $\mathrm{MBC}$ & male breast cancer \\
\hline MIC & micrometastasis \\
\hline MD & mammary ductoscopy \\
\hline MLO & mediolateral oblique \\
\hline $\mathrm{mm}$ & millimeter \\
\hline MRI & magnetic resonance imaging \\
\hline $\mathrm{n}$ & number \\
\hline NED & no evidence of disease \\
\hline neg & negative \\
\hline NFS & not further specified \\
\hline ni & no information \\
\hline NSLN & non-sentinel lymph node \\
\hline OS & overall survival \\
\hline $\operatorname{PgR}$ & progesteron receptor \\
\hline pos & positive \\
\hline REC & recurrent disease \\
\hline ROLL & Radioguided Occult Lesion Localization \\
\hline RRT & regional radiotherapy \\
\hline RT & radiotherapy \\
\hline SD & selective ductectomy \\
\hline SE & standard error \\
\hline
\end{tabular}


SLN sentinel lymph node

SLNB sentinel lymph node biopsy

TNM Tumor Node Metastases

US ultrasound

WBI whole breast irradiation

WBRT whole breast radiation therapy

WLE wide local excision 


\section{LIST OF FIGURES}

Figure 1: Example of a typical ductogram of a patient with single duct nipple discharge 11 .

Figure 2: Selective ductectomy

Figure 3: Microscopy of two representative cases of selective ductectomy specimens with intraductal papilloma

Figure 4: The hotspot of internal mammary sentinel lymph node on lymphoscintigraphy (anteroposterior view)

Figure 5: The technique of internal mammary sentinel lymph node biopsy: step by step

Figure 6: Changes in post-operative adjuvant therapy of patients with internal mammary sentinel lymph node biopsy

Figure 7: Lymph node involvement in axillary lymph node dissection and sentinel lymph node biopsy groups of patients with male breast cancer

Figure 8: Kaplan-Meier survival curves for the study population

\section{LIST OF TABLES}

Table 1: Summary of patients with a malignant diagnosis

Table 2: Summary of patients with precursor neoplastic lesions

Table 3: Summary of different types of operation in patients with successful internal mammary sentinel lymph node biopsy

Table 4: Characteristics of patients with successful internal mammary sentinel lymph node biopsy

Table 5: Characteristics of male breast cancers

Table 6: Summary of treatment of male breast cancers

Table 7: Basic characteristics of the patients analyzed

Table 8: Distribution of patients with low volume metastatic sentinel lymph node involvement according to their risk of non-sentinel lymph node metastasis based on the prediction by different predictive tools

Table 9: Details and main conclusions of larger internal mammary sentinel lymph node biopsy studies

Table 10: Summary of literature on male sentinel node biopsy in breast cancer

Table 11: Follow-up events of patients with sentinel lymph node involvement and no axillary lymph node dissection in published reports 


\section{INTRODUCTION}

Breast cancer is the most common malignant tumor in women. Previously, breast cancer was considered a loco-regional disease (Halsted theory) and the standard procedure for treatment was radical and supra-radical mastectomy. As a consequence, internal mammary (IM) lymph node dissection was part of the standard surgical treatment in some centers in the 1950s and 1960s. This radical surgical procedure was abandoned in the 1970s because patient outcome studies showed that radical dissection did not improve survival [1].

The paradigm shift in breast cancer surgery occurred in the 1980s with the spreading of the biological approach (Fisher theory) which stated that breast cancer is a systemic disease form the onset, therefore the radicality of the local treatment has not impact on the overall survival rate. Bernard Fisher and Umberto Veronesi found that conservative surgery complemented by radiotherapy (RT) resulted in a long-term outcome similar to mastectomy for both local recurrence and survival. This process was supported by the introduction and development of breast screening programmes, allowing the detection of ever smaller size tumors.

Currently, the majority of cases of breast cancer are detected at an early stage, with relatively small size and limited or no lymph node involvement. As a result of screening programmes, the average size of tumors and consequently the proportion of cases with lymph node involvement, especially those with massive lymph node involvement have decreased significantly $[2,3]$, more tumors are detected in an in situ, non-invasive state. This tendency has impacted on the surgical approach as the proportion of conservative operations in contrast to mastectomy has increased. From the mid-1990s, sentinel lymph node biopsy (SLNB) has become a widely used procedure, based on the assumption that not all axillary lymph nodes are equally likely to be involved, but there is one or there are some which have direct connection via afferent lymphatic vessels with the location of the primary tumor, and these are most probably affected by the first developing regional metastases.

The relevance of this theory was supported by many studies [4]. From the previous fundamental statement, the following one can also be deducted: if the sentinel lymph nodes (SLNs) are not involved, the metastasis free status of non-sentinel lymph nodes (NSLNs) is highly probable. The basic procedure for visualizing SLNs is lymphoscintigraphy, a procedure which can show the presence of not only axillary but also internal mammary sentinel lymph nodes (IM-SLNs). Biopsy of these latter has not become a routine surgical 
procedure. The same reasoning as the one leading to the introduction of SLNB has lead to questioning the need to perform axillary lymph node dissection (ALND) in all cases with SLN involvement.

Generally speaking, surgery of breast cancer has gradually become more and more conservative both at the primary site and the regional lymph nodes.

Single duct nipple discharge, especially when the fluid is blood stained, is a typical but not general and not specific initial symptom of breast cancer. This symptom may also be associated with central, subareolar intraductal papillomas or other papillary lesions [5].

The majority of solitary papillomas are benign, although they can be associated with cytological or structural atypia, in-situ or invasive malignancy [6]. Most intraductal papillomas are small (less than $5 \mathrm{~mm}$ in diameter), however papillomas as large as $10 \mathrm{~cm}$ have been reported [7]. Their standard diagnostic work-up includes mammography and ductography.

Most women presenting with nipple discharge have normal mammograms, but ductography may visualize intraductal lesions [8]. In addition, some investigators perform ultrasonography of the retro-areolar region to visualize enlarged ducts. Recently, magnetic resonance imaging (MRI) has been reported as a useful adjunct to ductography in the detection of intraductal papillomas, as well as malignancies with a significant intraductal component [9]. Ductoscopy is a new technical improvement allowing intraductal biopsy and therefore its introduction may be of help in the evaluation of intraductal lesions [10]. Ultrasound (US) guided vacuum assisted biopsy or removal of the lesion is another diagnostic option [11]. An alternative diagnostic procedure is the histological verification of intraductal lesions following selective ductectomy (SD), a conservative surgical excisional procedure aiming at the removal of the discharging duct with a minimal rim of periductal breast tissue.

The surgical treatment of breast cancer has substantially changed during the last decades. Lymph node status was the most important single prognostic factor of the disease and lymph nodes were removed for diagnostic (prognostic) and therapeutic purposes. SLNB has widely become the standard surgical procedure for axillary staging of clinically nodenegative patients, and preoperative clinical assessment has often been supplemented with axillary ultrasound (AXUS) and fine needle aspiration cytology (FNAC) or core needle biopsy (CNB) of suspicious nodes. If the SLNs contain no metastasis, no further axillary treatment is envisaged, and the omission of ALND in patients with negative SLNs has proved to be safe [12-16]. On the other extreme, clinically detected metastases in the axillary lymph nodes still require surgery, generally in the form of ALND. 
The two main nodal regions of the breast are the axillary and the parasternal or internal mammary (IM), the latter consisting of approximately 8 lymph nodes. Although studies of lymphatic drainage patterns report internal mammary chain (IMC) involvement in 13-35\%, the value of an SLN procedure for the IMC is still controversial [17-21]. Most authors do not perform IM-SLNB, because the clinical importance and therapeutical implications of IM-SLN metastases are unclear. Tumor location within the breast may influence the prevalence of IM nodal metastases. Medial tumors may have IM drainage somewhat more often than breast tumors at other locations, but tumor location alone has not been found to be a good predictor of IM-SLN involvement [22]. Whether the site of the primary breast tumor should be considered when deciding about IM-SLNB can also be a matter of debate. In addition to the axillary lymph node status, the IM lymph node status also provides prognostic information in breast cancer patients [23]. If positive, prognosis is less favourable. The worse prognosis can be expected in patients with involvement of both nodal regions, whereas patients with involvement of either region alone seem to have similar prognosis [22].

Although a positive SLN lead to an ALND in most patients, evidence suggests that a majority of SLN-positive patients do not have further lymph node involvement [24, 25]. It is even evident that further lymph node involvement does not manifest itself in recurrent disease in the majority of patients, provided adjuvant therapies are used according to current standards [26-29]. Therefore, omission of ALND has been a trend in at least a subset of SLNpositive patients for several years, even before the publication of the results of the American College of Surgeons Oncology Group (ACOSOG) trial Z-0011 [30-32]. Recent guideline recommendations acknowledge that limited SLN involvement does not necessarily require ALND in all patients $[33,34]$, and suggest that there is not need for ALND if the SLN involvement is at most micrometastatic [33, 34].

In contrast, the largest retrospective series of micrometastatic SLN patients suggest that there is a small minority of patients with SLN micrometastasis who have a significant risk and incidence of non-SLN (NSLN) involvement [35]. Nomograms devised for the prediction of NSLN metastasis in patients with micrometastatic SLNs suggest over $30 \%$ or close to $50 \%$ risk at their extremes [36-38]. On the basis of multivariate models, several factors affect the risk of NSLN involvement beside the size of the SLN metastasis [35-39]. Therefore, the omission of ALND in all micrometastatic SLN patients might be negligent. This is why follow-up data of patients with limited SLN involvement but no ALND is still important [34].

Compared to female breast cancer male breast cancer (MBC) is a rare disease representing less than $1 \%$ of all malignancies in men and only $1 \%$ of all incident breast 
cancers [40-43]. Due to the rarity of MBC, there is a lack of prospective clinical trials to define optimum treatment. Because of the low number of affected patients, treatment for MBC has been extrapolated from treatment protocols relating to breast cancer occurring in women. Mastectomy with axillary dissection is still the most commonly recommended procedure for MBC. There have been several reports on the use of SLNB in men, although the numbers of patients and length of follow-up have been limited [44-49]. 


\section{AIMS}

1. To analyze the role of selective ductectomy for the diagnosis and treatment of intraductal lesions presenting with single or rarely dual duct discharge and ductography suggestive of intraductal (papillary) lesions. To investigate the incidence of association of neoplastic proliferations or malignancy in this group.

2. To investigate in what percentage lymphoscintigraphy visualized IM-SLNs during the axillary SLNB (A-SLNB) operations performed in patients with invasive, clinically nodenegative breast cancer. To analyze in what proportion the IM-SLNB was successful in these patients, what was the rate of metastatic IM-SLNs and what were the factors influencing the presence of metastatic involvement. To assess to what extent the IM-SLN involvement has lead to a change in treatment.

3. To investigate the role of SLNB in MBC.

4. To asses the impact of omitting ALND in breast cancer patients with low volume SLN metastasis on locoregional recurrence and disease-free and overall survival. 


\section{PATIENTS AND METHODS}

3.1 Selective ductectomy for the diagnosis and treatment of intraductal papillary lesions presenting with single duct discharge.

Files of patients presenting with single (or rarely dual) duct discharge at the Department of Surgery or Breast Diagnostics of Bács-Kiskun County Teaching Hospital were retrospectively reviewed. Patients were evaluated and treated within a multidisciplinary setting, and whenever an intraductal obliteration (partial or complete) was evidenced by imaging studies, SD was considered as a diagnostic and therapeutic intervention. Only patient undergoing SD were further evaluated in this retrospective analysis. Bilateral two-viewmammography (craniocaudal - CC, and mediolateral oblique - MLO), ultrasonography and ductography were performed in all patients. For ductography, $2 \mathrm{ml}$ contrast media (Ultravist iopromide, Bayer, Berlin, Germany) was injected through a 27 gauge cannula (Anel, LuerLock, Medicor, Debrecen, Hungary) into the discharging duct, then CC and MLO views of the given breast were obtained. Spot compression magnification views of the area of concern were also analyzed. The suspicion of a papilloma was raised when a regular intraluminal filling defect was seen. (Fig. 1).

Nipple discharge cytology was evaluated in all cases. Whenever a mass lesion was also identified by US, US-guided FNAC or CNB was also done. Biopsy of microcalcifications was performed under stereotactic guidance using 14-gauge needle and a biopsy gun. Surgical excision was recommended on the basis of suspected intraductal papilloma (IP). SD was performed in the following steps. At the beginning of the operation, the nipple was compressed in order to visualize the duct with the discharge. One $\mathrm{ml}$ of Patent blue dye (Laboratories Guerbet, Roissy, France) was injected through a 27-gauge cannula inserted into the pathologic duct. Following this vital labelling of the duct, an infraareolar incision was made and the areolar flap was raised. The pathological duct was identified and the dyed 3 or $4 \mathrm{~cm}$ long part was removed with a small rim of surrounding breast tissue. The specimens were oriented with a short suture at the mammillary edge and a long suture at the peripheral edge (Fig. 2). 


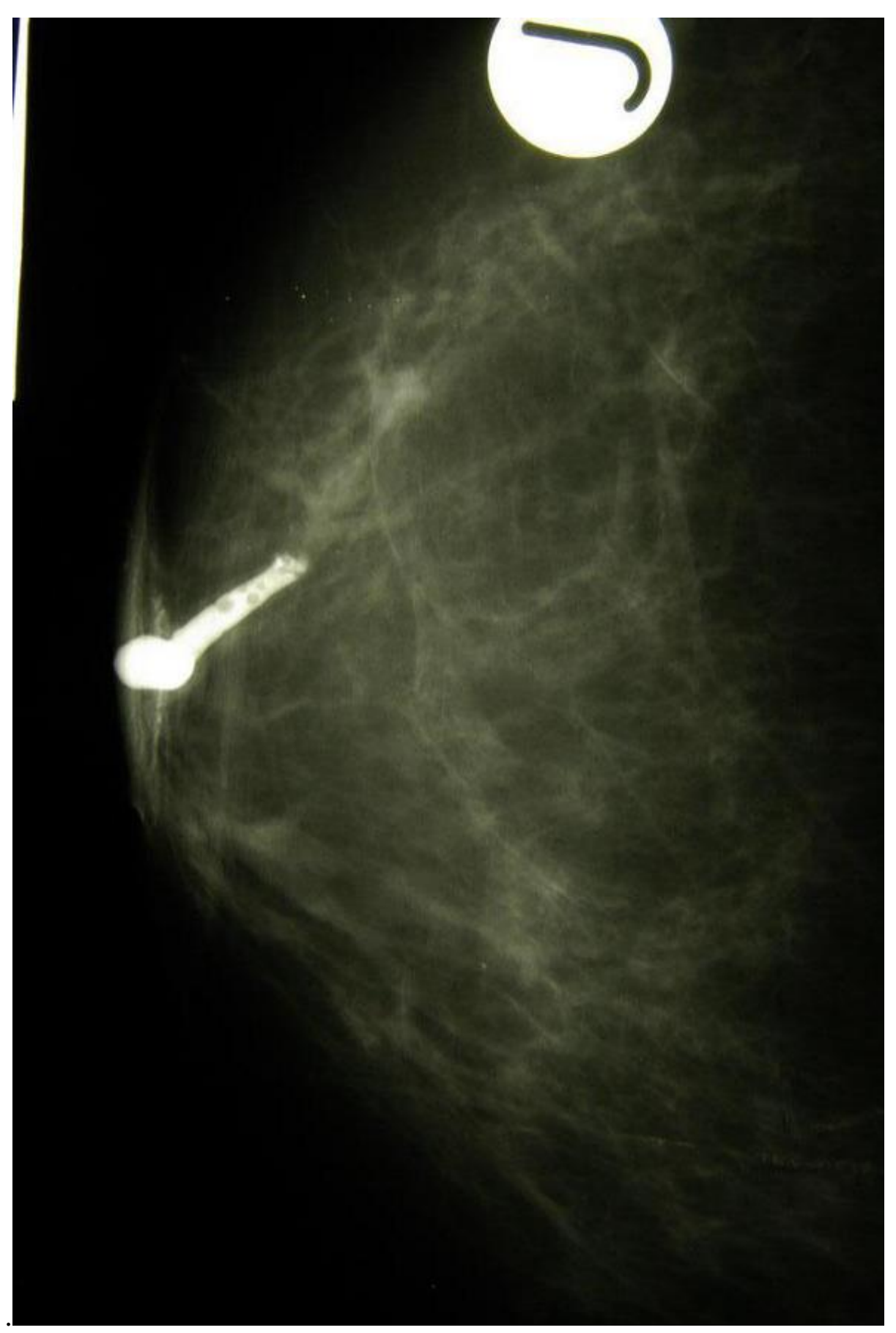

\section{Figure 1}

Title:Example of a typical ductogram of a patient with single duct nipple discharge Description:The dilated duct fills up partially, is amputated at the end and shows irregularities suggestive of intraluminal protrusions. 


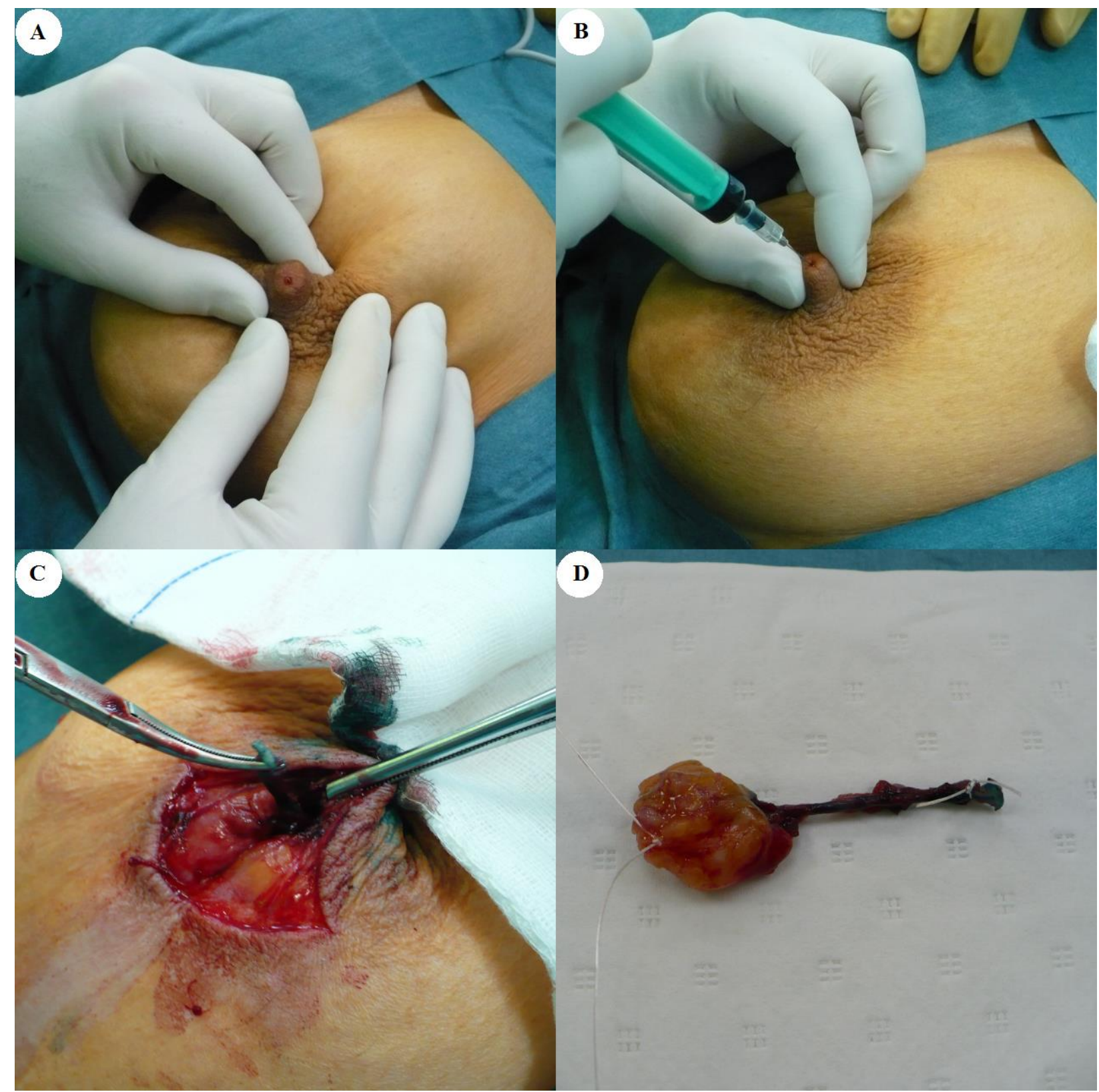

\section{Figure 2}

Title: Selective ductectomy

Description:

A: Identification of the duct responsible for the discharge.

B: Cannulation of the discharging duct and administration of the vital dye into the duct.

C: Removal of the cannulated blue stained duct from an infraareolar incision.

D: The specimens were oriented with a short suture at the mammillary edge and a long suture at the peripheral edge. 
At the time of introduction of SD, a few cases were also injected intraductally with radiological contrast material ( $2 \mathrm{ml}$ Ulravist) to allow radiological detection of the lesion after the removal of the duct. All ducts removed were sent for histological examination. Following fixation in $10 \%$ buffered formalin, the ducts were sliced perpendicular to their long axis from the central part towards the periphery, and were blocked in consecutive transsectional planes. The central and peripheral slices were always submitted for histological analysis, whereas the rest of the duct was either submitted in toto or only the slices including the grossly identifiable intraductal lesion were embedded in paraffin. Tissue sections were stained with hematoxylin and eosin (Fig. 3).

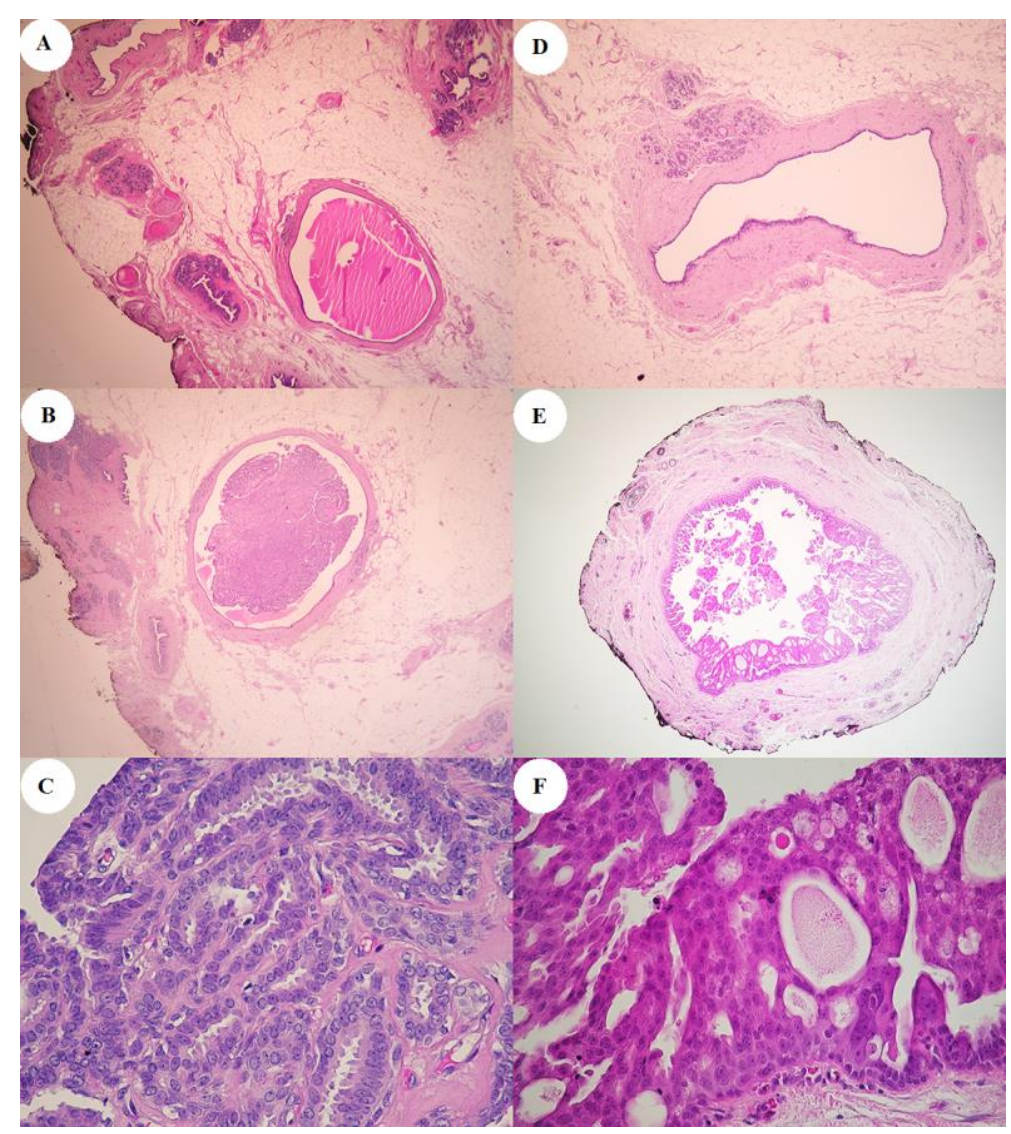

\section{Figure 3}

Title: Microscopy of two representative cases

Description: A-D Selective ductectomy specimen with intraductal papilloma. Proximal (close to the nipple) (A) and distal (away from the nipple) (D) transections show a dilated duct with periductal fibrosis, but no intraductal proliferation. Similar findings also suggest proliferation free longitudinal margins. Transsections falling between the two edges showed an intraductal papilloma (B) without atypia (C). E-F Selective ductectomy specimen with intermediate grade cribriform DCIS. (Hematoxylin and eosin, A, B, D, E: $\times 20 ; \mathbf{C}, \mathbf{F}: \times 400$ ) 
Results were categorized as isolated benign papilloma, papilloma associated with high-risk lesions such as atypical ductal type epithelial hyperplasia (ADH), lobular intraepithelial neoplasia (LN) or ductal carcinoma in situ (DCIS) and papilloma/atypical papilloma associated with invasive ductal carcinoma (IDC). Some non-papillary lesions fell outside of these categories and they also included malignant disease without papillary growths.

3.2 Internal mammary sentinel lymph node biopsy in breast cancer. Is it indicated?

Selective ALND based on A-SLNB results was introduced in our hospital with the approval of the local ethical committee. Between January 2001 and June 2012, 1542 patients with clinically node-negative operable primary breast cancer gave an informed consent and underwent SLNB. Except for pregnancy and T4 tumors, no patients were excluded. The preoperative diagnosis of breast cancer was established by mammography, ultrasonography and FNAC or CNB in all patients. Prior to surgery, AXUS was performed routinely and if suspicious lymph nodes were identified, FNAC was also done [50-52]. When this revealed an axillary lymph node metastasis, ALND was performed, whereas in case of negative cytology findings, A-SLNB was the staging procedure done. Our technique of SLNB involved intraparenchymal administration (intra- and/or peritumoral injection in 3-4 depots) of 60-90 MBq 99mTc-labelled colloids the day before surgery: either 200-600 nm particle size Sentiscint (Medi-Radiopharma Kft., Érd, Hungary) or 40-80 nm particle size colloids Nanoalbumon (Medi-Radiopharma Kft., Érd, Hungary) or Nanocoll (Gipharma, Saluggia, Italy). From January 2006, we introduced superficial, periareolar injection of the radiocolloid according to the localization of the quadrant harboring the tumor as preferred method.

However, in case of non-palpable tumors, the radioactive tracer was injected intraparenchymally, into and around the tumor, with US guidance to permit Radioguided Occult Lesion Localization (ROLL) [53]. Lymphoscintigraphy was generally performed 2 hours after the administration of the radioactive tracer and was often repeated the next day, shortly before surgery, to check whether the highlighted lymph nodes are still there and no further lymph nodes have appeared. Lymphoscintigraphic images were obtained in two standard positions: anteroposterior and MLO. The location of the non palpable tumors, axillary SLNs (A-SLNs) and IM-SLNs was marked on the skin. Two ml Patent Blue dye was 
injected intraparenchymally above the tumor after the induction of general anesthesia, 10-15 min before the incision. Harvesting both axillary and IM-SLNs was attempted in all patients, as visualized on lymphoscintigraphy (Fig.4).

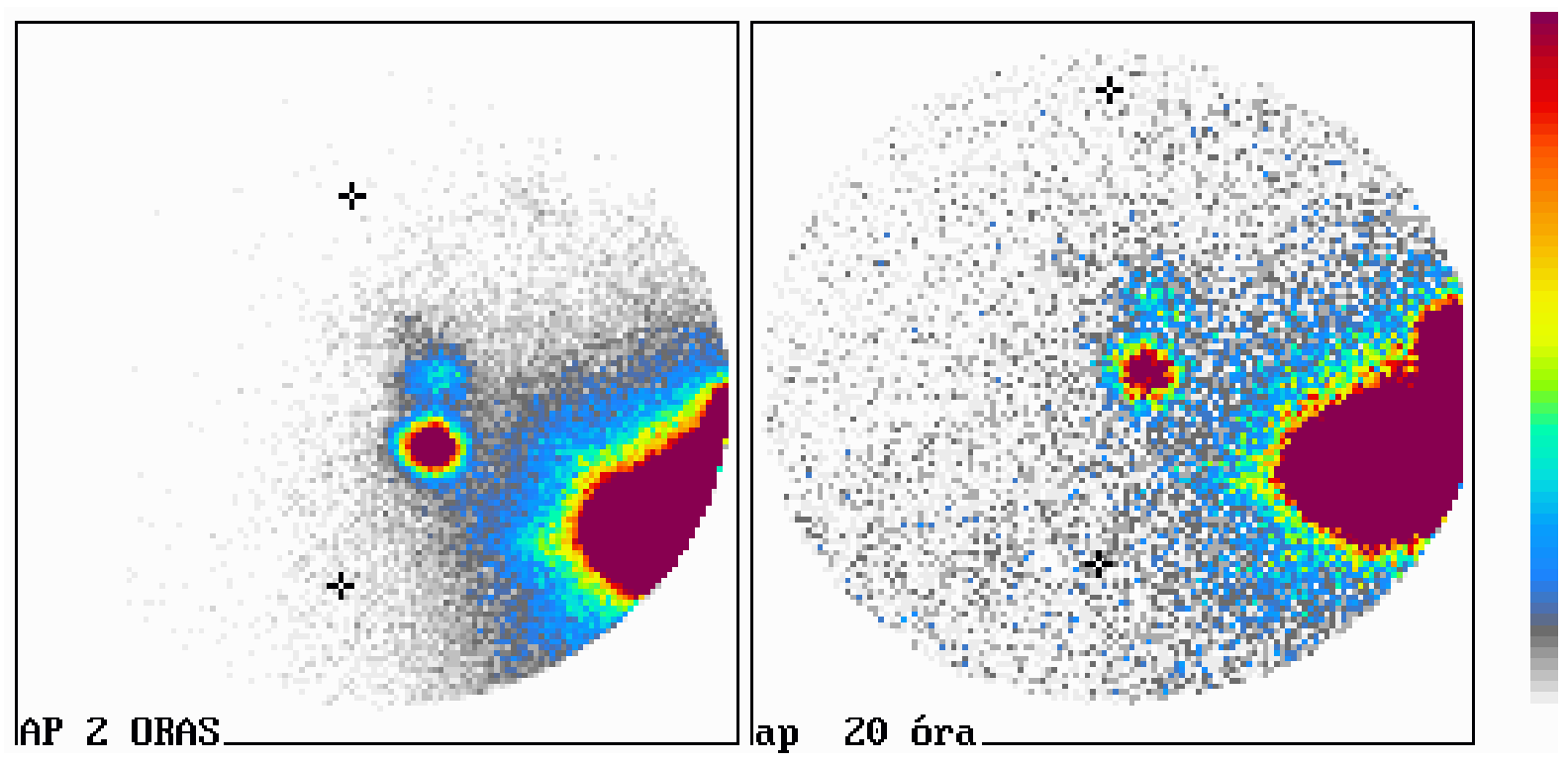

\section{Figure 4}

Title: The hotspot of an internal mammary sentinel lymph node (IM-SLN) on lymphoscintigraphy (anteroposterior view)

Description: The IM-SLN hotspot was visualized on lymphoscintigraphy in the parasternal location after $2 \mathrm{~h}(\mathrm{a})$ and after $20 \mathrm{~h}(\mathrm{~b})$.

A-SLNB was performed before the removal of the primary carcinoma and A-SLNs sliced at about $2 \mathrm{~mm}$ intervals were subjected to imprint cytology as a means of intraoperative evaluation, to allow immediate ALND in patients with metastasis. The primary breast tumor was removed next by either breast conserving methods or by mastectomy, according to the tumor and patient characteristics, and the consent obtained prior to the operation. This was followed by IM-SLNB whenever lymphoscintigraphy highlighted IMC drainage. The IMSLNB technique, based on the IM-SLNB method described by van der Ent [19] can usually be performed using the mastectomy incision. In breast conserving operations, a small additional horizontal incision $(2.5-3 \mathrm{~cm})$ over the desired interspace was used to sample IMSLNs. It is usually preferable that this incision does not cross the midline, because of cosmetic reasons. The pectoral major muscle was exposed for 2 to $3 \mathrm{~cm}$ directly over the desired interspace. The muscle fibers were then separated to expose the posterior intercostal 
space. The external and internal intercostal muscles are divided transversely from the sternal border in a lateral direction for 3 to $4 \mathrm{~cm}$. In cutting the internal intercostal muscle, particular care must be taken to avoid injury to the inferior parietal pleura or the internal mammary artery (Fig. 5).

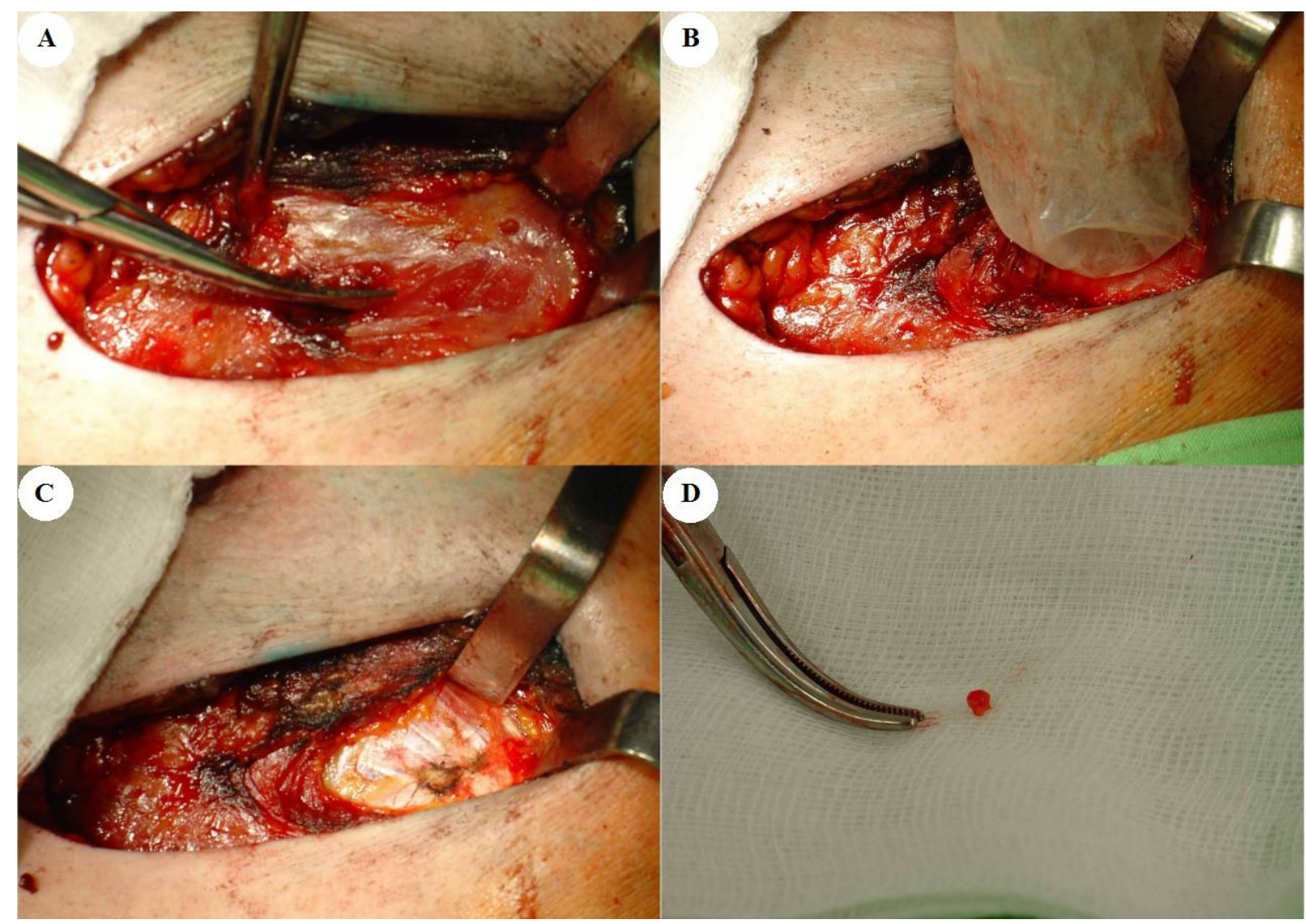

\section{Figure 5}

Title: The technique of internal mammary sentinel lymph node (IM-SLN) biopsy: step by step Description:

A: The fibers of the major pectoral muscle are separated to expose the posterior intercostal space.

B: Intraoperative identification of the IM-SLN hotspot with the help of the gamma probe.

C: The intercostal muscles were separated from the lower rib to expose the fatty tissue along the internal mammary vessels on the surface of the parietal pleura.

D: The harvested IM-SLN, which is typically smaller $(0.5-2 \mathrm{~mm})$ than the A-SLN and rarely stains blue.

In case of multiple IM hotspots on the lymphoscintigraphy, the IM lymph nodes were mostly retrieved through the same incision. Intraoperative identification of the A-SLNs and IM-SLNs was based both on blue dye mapping and gamma probe detection (C-Trak Surgical 
Guidance System, Care Wise Medical Products Corporation, Morgan Hill, CA, USA). IMSLNs were not subjected to intraoperative assessment. The final pathological evaluation of all SLNs included formalin fixation, paraffin embedding and step sectioning at $250 \mu \mathrm{m}$ intervals of all slices or unsliced lymph nodes smaller than $6 \mathrm{~mm}$ with hematoxylin and eosin staining of all, and cytokeratin immunohistochemistry of several levels [54]. Metastases in the ASLNs discovered only in the permanent sections also generally resulted in ALND with the exception of a few patients. As the largest part of the study period used the 6th edition of the Tumor Node Metastases (TNM) classification of malignant tumors, this edition was used for staging purposes and the discrimination of metastases, micrometastases (MIC) and isolated tumor cells (ITC) [55]. Statistical analysis for the comparisons included the chi-square test for categorical variables and the student $t$ test for continuous variables. The significance level was set at $\mathrm{p}<0.05$.

3.3 The role of sentinel node biopsy in male breast cancer.

Twenty-five MBC patients were operated on between January 2004 and August 2013. The majority of patients with MBC presented with a painless, subareolar mass, often associated with nipple retraction or discharge [56]. At the beginning of the study period, mastectomy was performed with immediate ALND, without attempting SLNB. The reasoning behind this policy was as follows: the size of tumors in males is typically larger compared to females, larger tumors are more often accompanied by lymph node metastases, and there were insufficient data on the role of SLNB in male patients. This approach was used in 9 patients. From 2004 the preoperative diagnosis of MBC, similarly to breast cancer in women was established by mammography, ultrasonography and FNAC or CNB in all patients. Prior to surgery, AXUS was performed routinely and if suspicious lymph nodes were identified, FNAC was also done [50-52]. When this revealed an A-SLN metastasis, ALND was performed, whereas in case of negative cytology findings, A-SLNB was the staging procedure done.

AXUS routinely performed in all but a few patients at the beginning of the study period often helped in the demonstration of axillary lymph node involvement, as men were frequently diagnosed with locally advanced disease [57].

Survivors were asked to complete a postoperative questionnaire about the subjective aspects of the disease. The questions referred to previous knowledge of the existence of MBC, family history, main apprehension when finding out the diagnosis of breast cancer (surgery, 
chemo-, hormonal or radiotherapy, work-related issues, sexual activity problems). The other set of questions referred to complaints relating to any motoric or sensorial dysfunctions on the operated side (arm, hand). The last set of questions was about fears of breast cancer recurrence.

3.4 Regional disease control in selected patients with sentinel lymph node involvement and omission of axillary lymph node dissection.

After the introduction of SLNB in August 1997 and a rather long learning period, early breast cancer patients with clinically node-negative disease presenting at the BácsKiskun County Teaching Hospital were routinely offered SLNB from October 2000. The methods used were similar to those described in section 3.2. These included step sectioning of the sliced SLNs and cytokeratin immunohistochemistry (IHC) at multiple levels. Initially the SLNs were sectioned till the extinction of the tissue blocks [54], but from July 2012, after an initial trimming, only three layers separated by 250 microns were taken with IHC at the beginning and the end of the 3 steps. All patients with positive SLN findings on intraoperative or final histology were offered ALND. ITCs were considered negative nodal findings in this respect, according to the TNM recommendations, and patients with minimal nodal involvement belonging to this category were generally not offered ALND. Later a number of micrometastatic patients were also spared ALND, and a few patients with larger metastases also skipped completion ALND by not consenting to this operation.

Radiotherapy and systemic therapy was given according to national guidelines valid at the time of their management. Patients were followed as outpatients, and follow-up included six monthly mammographic and ultrasonographic assessment (including the examination of the axilla) in the first 3 years, and yearly imaging controls thereafter. Clinical controls were scheduled every 6 months in the first 5 years following breast surgery. Patients lost to follow-up within the first 12 months were not considered suitable for this retrospective analysis. The Kaplan-Meier survival estimates were used for overall, disease free and breast cancer specific survivals.

Patients with SLN metastatic involvement not larger than $2 \mathrm{~mm}$ were analyzed for the risk of NSLN involvement with 3 nomograms devised for micrometastatic disease [36-38]. A low risk of NSLN involvement was defined as a nomogram predicted risk not greater than $10 \%$. Accordingly, a nomogram based risk of more than $10 \%$ was classified as high risk. For 
the fourth predictive tool, the presence of 0 or 1 of 5 risk factors (tumor size $>2 \mathrm{~cm}$, lymphovascular invasion, hormone receptor negativity, localisation in the upper outer quadrant, involved SLN ratio >33\%) was used to define low risk patients with micrometastatic SLNs, as this was associated with around 10\% frequency of NSLN metastasis in the original description [35]. Likewise, for SLNs harbouring ITC, the presence of 0 to 1 of 3 risk factors (age younger than 40 years, tumor size $>2 \mathrm{~cm}$, involved SLN ratio of $100 \%$ ) were considered to have low risk of NSLN metastasis [35].

Disease related events of patients classified as having high versus low risk were compared with the Fisher exact test, and the significance level of the two sided test was set at p $<0.05$ (VassarStats, Richard Lowry, Vassar College, Poughkeepsie, New York, USA; http://vassarstats.net). All patients gave an informed consent. Data were anonymized and the institutional data safety monitor approved their handling in such a way. The institutional ethical committee of Bács-Kiskun County Teaching Hospital approved this non-interventional retrospective analysis.

\section{RESULTS}

4.1 Selective ductectomy for the diagnosis and treatment of intraductal papillary lesions presenting with single duct discharge.

The retrospective review of records between January 2004 and January 2011 revealed 100 patients with suspected intraductal papillary proliferations removed by ductectomy. The mean age of the patients was 52 years (range: 32- 82 years). Nipple discharge was the main clinical symptom in all of them. Mammography was normal in 83 cases and showed microcalcifications in 17 cases. US described a mass in 23 cases. A single duct discharge was identified in 98 cases and dual duct excretion was seen in 2 cases. The fluid discharged from the duct was serous in 77 cases and blood stained in 23. Cytological examination of the fluid discharged from the duct reported normal cells (C2) in 60 patients and showed atypical, probably benign cells (C3) in 40 cases [58]. CNB was obtained in 4 cases. All of them were B3 (breast tissue with uncertain malignant potential) lesions, corresponding to intraductal papilloma $(n=3)$ and sclerosing adenosis $(n=1)$ on final histology.

The operations were performed under general anesthesia. The average operation time was 17 minutes. We did not have any serious complications. Twelve patients had a mild discomfort in the breast wound for a day or two. 
The histopathological findings of the surgically excised lesions revealed benign papilloma in 62 patients, papilloma with ADH within the papillary lesion (atypical papilloma) in 5, papilloma with $\mathrm{ADH}$ around the papillary proliferation in 4, papilloma with $\mathrm{LN}$ around the lesion in 1, an apocrine papillary lesion without myoepithelium in the central part and with partial lack of myoepithelium at the periphery in 1 [59], DCIS in 4 and IDC, (of which the name preferred by the current World Health Organization classification is invasive carcinoma of no special type) in 2 patients (Tables 1 and 2).

Three of the DCIS cases and one of the IDC cases were also associated with papillomas (Table 1). Ductectasia was the only finding in 16 patients and other benign changes were seen in 5 cases. This means that out of 100 patients presenting with single duct discharge and ductographic changes suggestive of intraductal (papillary) proliferations, 6 $(6 \%)$ proved to have malignant disease (4 in situ and 2 invasive carcinomas). Furthermore, 14 intraductal papillomas (18\% of papillomas, $14 \%$ of all cases) were associated with neoplastic changes: atypical hyperplasia found in 5 and around 5 of them (Table 2), in situ carcinoma associated with 3 and invasive carcinoma with 1 of them (Table 1), whereas 2 malignant cases had no papillary proliferation at all.

Considering the six patients with a final diagnosis of DCIS or IDC and the 10 patients with precursor neoplastic lesions ( $\mathrm{ADH}$ or $\mathrm{LN})$, mammography showed microcalcifications in two cases and ultrasonography found a mass in two (Tables 1 and 2). From the 6 malignant lesions, nipple discharge cytology resulted in $\mathrm{C} 2$ and $\mathrm{C} 3$ in three cases each. The initially performed selective ductectomy was complemented in all cases with ROLL [53] and breast conserving surgery plus SLNB. One of the patients needed a third operation, because of the positive margins of the second specimen: due to the extent of the lesion and no signs of it on imaging studies including breast MRI, the third operation consisted of mastectomy, followed by reconstruction with an implant. The SLNs were negative in all cases. Whole breast irradiation was delivered to 4 patients with total doses of $50 \mathrm{~Gy}$. Two of them also received boost irradiation to the tumor bed because of close margins. Two patients were given chemotherapy because of grade 3 IDC and a premenopausal status. Estrogen receptor (ER) was positive in 5 tumors. All of these patients received hormonal therapy (HT) (Table 1). 
Table 1 Summary of patients with a malignant diagnosis

\begin{tabular}{|c|c|c|c|c|c|c|}
\hline Patient & Age & Imaging & Surgery & Histology/TNM Staging & Size (margins) $)^{\mathrm{a}}$ & $\begin{array}{l}\text { Adjuvant } \\
\text { treatment }\end{array}$ \\
\hline 1 & 76 & & SD followed by reexcision & $\begin{array}{l}\text { IG DCIS pTis pNxM0 + intraductal papilloma } \\
\text { ER: pos PgR: pos Her-2: neg }\end{array}$ & $36(0)^{b}$ & $\mathrm{HT}$ \\
\hline 2 & 33 & & $\begin{array}{l}\text { SD followed by WLE and } \\
\text { SLNB followed by } \\
\text { mastectomy and breast } \\
\text { reconstruction }\end{array}$ & $\begin{array}{l}\text { HG DCIS pTis pN0/i-/M0 } \\
\text { ER: neg PgR: neg Her-2: pos }\end{array}$ & $\begin{array}{l}44 \\
(0.1 \text { posterior })\end{array}$ & \\
\hline 3 & 48 & $\begin{array}{l}9-\mathrm{mm}- \\
\text { large cyst } \\
\text { on US }\end{array}$ & $\begin{array}{l}\text { SD followed by WLE and } \\
\text { SLNB }\end{array}$ & $\begin{array}{l}\text { IDC G III pT1c pN0/sn/M0 + intraductal } \\
\text { papilloma } \\
\text { ER: pos PgR: pos Her-2: neg }\end{array}$ & $\begin{array}{l}13 \\
(0.6 \text { posterior })\end{array}$ & $\begin{array}{l}\text { WBRT and ChT } \\
\text { and HT }\end{array}$ \\
\hline 4 & 54 & $\begin{array}{lr}25 \times 15 & \mathrm{~mm} \\
\text { mass } & \text { on } \\
\text { US } & \\
\end{array}$ & $\begin{array}{l}\text { SD followed by WLE and } \\
\text { SLNB }\end{array}$ & $\begin{array}{l}\text { IDC G II extensive DCIS component.pT1b } \\
\text { pN0/sn/M0 } \\
\text { ER: pos PgR: pos Her-2: neg }\end{array}$ & $\begin{array}{l}6 \text { (invasive), } 48 \\
\text { (whole) } \\
(1 \text { posterior) }\end{array}$ & $\begin{array}{l}\text { WBRT and ChT } \\
\text { and HT }\end{array}$ \\
\hline 5 & 57 & & $\begin{array}{l}\text { SD followed by WLE and } \\
\text { SLNB }\end{array}$ & $\begin{array}{l}\text { LG/IG DCIS pTis pN0/i-/M0 + intraductal } \\
\text { papilloma } \\
\text { ER: pos PgR: pos Her-2: neg }\end{array}$ & $29(>10)$ & WBRT and HT \\
\hline 6 & 66 & & $\begin{array}{l}\text { SD followed by WLE and } \\
\text { SLNB }\end{array}$ & $\begin{array}{l}\text { LG DCIS pTis pN0/i-/M0 }+ \text { intraductal } \\
\text { papilloma } \\
\text { ER: pos PgR: pos Her-2: neg }\end{array}$ & $27(8)$ & WBRT and HT \\
\hline
\end{tabular}

ChT: chemotherapy; DCIS: ductal carcinoma in situ; ER: estrogen receptor; HER-2: human epidermal growth factor receptor 2; HG: high grade; HT: hormonal therapy; IG: intermediate grade; LG: low grade; mm: millimeter; neg: negative; PgR: progesteron receptor; pos: positive; SD: selective ductectomy; SLNB: sentinel node biopsy; TNM: Tumor Node Metastases; WBRT: whole breast radiation therapy; WLE: wide local excision.

a all measures are in mm (closest margin)

$\mathrm{b}$ reexcision indicated, but patient denying 
Table 2 Summary of patients with precursor neoplastic lesions

\begin{tabular}{|c|c|c|c|c|c|c|}
\hline Patient & Age & $\begin{array}{l}\text { Mammography and/or } \\
\text { ultrasound findings }\end{array}$ & Surgery & Histology & margins & Follow-up information \\
\hline 1 & 68 & & SD & $\begin{array}{l}\text { Papilloma and } \mathrm{ADH}+\mathrm{CCA} \\
\text { around }\end{array}$ & free, NFS & 9 month NED, LFU \\
\hline 2 & 61 & & SD & AP, NED around the papilloma & free, NFS & LFU \\
\hline 3 & 50 & $\begin{array}{l}\text { 4-mm-large } \\
\text { microcalcification }\end{array}$ & $\begin{array}{l}\text { SD with wire } \\
\text { localization }\end{array}$ & $\begin{array}{l}\text { Papilloma and } \mathrm{ADH}+\mathrm{CCA} \\
\text { around; microcalcification in } \\
\text { the papilloma and the CCA }\end{array}$ & free, NFS & 71 month NED \\
\hline 4 & 55 & $\begin{array}{l}\text { 15-mm-large mass with } \\
\text { microcalcification }\end{array}$ & $\begin{array}{l}\text { SD with wire } \\
\text { localization }\end{array}$ & $\begin{array}{l}\text { AP, NED around the } \\
\text { papilloma; microcalcification } \\
\text { in the lesion }\end{array}$ & free, $2-3 \mathrm{~mm}$ & LFU \\
\hline 5 & 46 & & SD & AP, NED around the papilloma & $\begin{array}{l}\text { duct opened, } \\
\text { possibly } \\
\text { involved } \\
\end{array}$ & 43 month NED \\
\hline 6 & 66 & & SD & $\begin{array}{l}\text { Papilloma and } \mathrm{ADH}+\mathrm{CCA} \\
\text { around }\end{array}$ & $0.3 \mathrm{~mm}$ & 74 month NED \\
\hline 7 & 61 & & SD & AP, NED around the papilloma & free, NFS & 41 month NED \\
\hline 8 & 43 & & $\begin{array}{l}\text { SD with wide } \\
\text { excision }\end{array}$ & $\begin{array}{l}\text { Papilloma with radial scar } \\
\text { associated with ADH around }\end{array}$ & $\begin{array}{l}\text { not assessable, } \\
\text { removed in } 2 \\
\text { pieces }\end{array}$ & 45 month NED \\
\hline 9 & 32 & & SD & AP, NED around the papilloma & free, NFS & LFU \\
\hline 10 & 53 & & SD & $\begin{array}{l}\text { Papilloma with lobular } \\
\text { neoplasia outside }\end{array}$ & $\begin{array}{l}\text { crossing lobular } \\
\text { neoplasia }\end{array}$ & 36 month NED \\
\hline
\end{tabular}

ADH: atypical ductal hyperplasia; AP: atypical papilloma (i.e. papilloma with atypical ductal type hyperplasia within the papilloma); CCA: columnar cell alterations encompassing columnar cell changes and hyperplasia without atypia and flat epithelial atypia; LFU: last follow up; mm: millimeter; NED: no evidence of disease; NFS: not further specified; SD: selective ductectomy. 
4.2 Internal mammary sentinel lymph node biopsy in breast cancer. Is it indicated?

A total of 1542 consecutive breast cancer patients with an attempted A-SLNB between January 2001 and June 2012 were included in this review. All but 13 patients were women. The A-SLNB was successful in 1485 cases, $96 \%$ of the patients. At least one A-SLN was involved in 606 cases, i.e. $41 \%$ of the patients. Only the data of the 77 patients who had IMSLNB were analyzed in details. The histological type of the tumors was as follows: invasive carcinoma of no special type (IDC) $(n=54)$, invasive lobular $(n=11)$, mixed ductal and lobular $(n=2)$, tubular $(n=5)$, medullary, micropapillary, tubulolobular, metaplastic and mucinous carcinoma ( $\mathrm{n}=1$ each). The operations performed are summarized in Table 3.

Table 3 Summary of different types of operation in patient with successful IM-SLNB

\begin{tabular}{|l|l|l|}
\hline Characteristic & IM-SLN- $(\mathrm{n}=63)$ & $\begin{array}{l}\text { IM-SLN+ } \\
(\mathrm{n}=14)\end{array}$ \\
\hline Type of the operation & & \\
\hline ROLL+A-SLNB+IM-SLNB & 31 & 5 \\
\hline ROLL+A-SLNB+ALND+IM-SLNB & 5 & 3 \\
\hline BCS+A-SLNB+IM-SLNB & 21 & 4 \\
\hline BCS+A-SLNB+ALND+IM-SLNB & 3 & 0 \\
\hline Mastectomy+A-SLNB+IM-SLNB & 3 & 1 \\
\hline $\begin{array}{l}\text { Mastectomy+A-SLNB+ALND+IM- } \\
\text { SLNB }\end{array}$ & 0 & 1 \\
\hline
\end{tabular}

ALND: axillary lymph node dissection; A-SLNB: axillary sentinel lymph node biopsy; BCS: breast conserving surgery; IM-SLN: internal mammary sentinel lymph node IM-SLNB: internal mammary sentinel lymph node biopsy; n: number; ROLL: radioguided occult lesion localization

IM-SLNs were visualized on preoperative lymphoscintigraphy in 83 of the 1542 patients (5.4\%), IM-SLNB was successful in 77 cases (93\%). Of the 6 failed attempts to remove an IM-SLN, the uptake of the SLN was low in one case: although the IM-SLN was visualized the day before surgery, it vanished by the next day. The gamma-probe went wrong during the operation in a second case. The mean age of patients with successful IM-SLN mapping was 56.5 years (range: 33-77). The median tumor size was $14.5 \mathrm{~mm}$. IM-SLNs were mostly found in the second or third interspace. This node was typically smaller $(0.5-2 \mathrm{~mm})$ 
than the A-SLN. The IM-SLN stained blue in only 11 patients (14\%). A total of 86 IM-SLNs were dissected (mean1.1). IM-SLN involvement was identified in 14 cases, which represents $18 \%$ of patients who underwent IM-SLNB. This included macrometastases (MAC) in 5 cases, MIC in 2 cases, ITC in 7 cases. In the IM-SLNB group, we removed 114 A-SLNs (average 1.84). Axillary involvement was found in 16 cases (20\% of the 77 patients) and consisted of ITC in 3 cases, MIC in 6 and MAC in 7. No significant differences were found between patients with and without IM-SLN involvement in terms of age, tumor location, tumor size, axillary involvement, tumor grade or ER status (Table 4).

Table 4 Characteristics of patients with successful IM-SLNB

\begin{tabular}{|l|l|l|l|}
\hline Characteristic & IM-SLN- $(\mathrm{n}=63)$ & IM-SLN+ $(\mathrm{n}=14)$ & P-value \\
\hline Age & & & 0.47 \\
\hline$\leq 50$ & 21 & 3 & \\
\hline $51-70$ & 36 & 9 & \\
\hline$>70$ & 6 & 2 & \\
\hline Tumor location & & & 0.41 \\
\hline Lateral & 39 & 7 & \\
\hline Medial or Central & 24 & 7 & \\
\hline Tumor size & & & 0.37 \\
\hline$\leq 20$ mm & 47 & 12 & \\
\hline$>20$ mm & 16 & 2 & \\
\hline Axillary nodal status & & & 0.41 \\
\hline Negative & 49 & 8 & \\
\hline Positive & 14 & 4 & 0.14 \\
\hline Tumor histological grade & & & \\
\hline I & 16 & 6 & \\
\hline II & 30 & 4 & 0.15 \\
\hline III & 17 & 4 & \\
\hline Estrogen receptor status & & 0 & \\
\hline Negative & 8 & 14 & \\
\hline Positive & 55 & & \\
\hline
\end{tabular}

IM-SLN: internal mammary sentinel node; IM-SLNB: internal mammary sentinel node biopsy; mm: millimeter; $\mathrm{n}$ : number

In 10 cases (13\% of the IM-SLNB patients) the IM-SLN was involved without ASLN involvement. Of these patients, the IM-SLN involvement has lead to new therapeutical indications in 2 cases (3\% of all IM-SLNB patients), both of them due to MAC in the IMSLN. One patient had a change in chemotherapy and one had a change in RT with the addition of irradiation of the IMC (Fig. 6). 
Figure 6 Changes in post-operative adjuvant therapy of patients with IM-SLNB

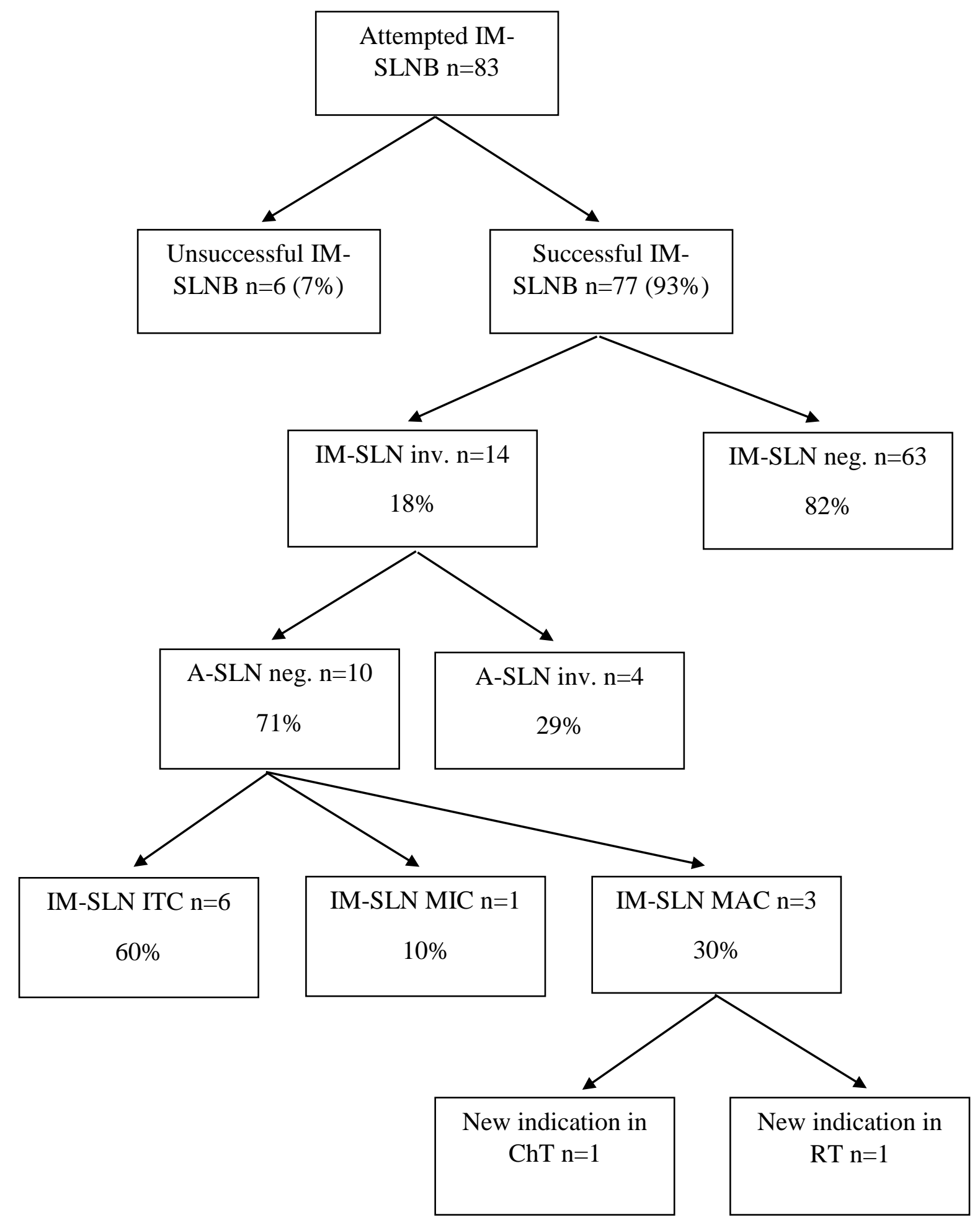

A-SLN: axillary sentinel lymph node; ChT: chemotherapy; IM-SLN: internal mammary sentinel lymph node; IM-SLNB: internal mammary sentinel lymph node biopsy; ITC: isolated tumor cells; inv: involvement; MAC: macrometastases; MIC: micrometastases; n: number; neg: negative; RT: radiotherapy 
The patients who had undergone successful IM-SLNB were followed until June 2012, their follow-up included AXUS, and no evidence of loco-regional recurrence was noted. Median follow-up time was 46 month (range: 2-121 month). Three of the 77 patients in this study died, one of distant metastases of breast cancer in the liver, and two of unrelated causes (rectal cancer and cardiorespiratory insufficiency).

IM-SLNB had few complications. Out of the 83 patients in whom IM-SLNB was attempted, minor complications were seen in 8 cases $(9.6 \%)$. Pleural lesions occurred in 5 patients (none of them needed thoracic drainage), the injury of the IM artery occurred in 2 cases and the injury of a minor thoracic vein in 1 case, all three vascular lesions were solved by ligation of the respective artery or vein, with no additional incision. There was also one major complication (1.2\%): a major retrocostal leak of the IM artery requiring partial resection of two adjacent ribs to allow its restauration. The latter patient is well and alive with no evidence of disease after 12 months of follow up at the time of writing.

4.3 The role of sentinel node biopsy in male breast cancer.

A total of 25 consecutive MBC patients were included in this review. Sixteen of them (64\%) had SLNB. The SLNB was successful in all cases. The remaining 9 patients (36\%) had primary ALND. The data of the 25 patients who had SLNB or ALND were analyzed in detail. The histological type of the tumors was as follows: IDC $(n=21)$, invasive lobular $(n=$ $2)$, invasive cribriform $(n=1)$ and mixed invasive micropapillary carcinoma $(n=1)$. No significant differences were found between patients with SLNB or ALND in terms of age, tumor location, axillary involvement, tumor grade or ER and human epidermal growth factor receptor 2 (HER-2) status (Table 5). The only significant difference was in tumor size, with larger tumors found in the ALND patients. Breast conserving surgery was performed in only 1 patient. 
Table 5 Characteristics of male breast cancers

\begin{tabular}{|l|l|l|l|}
\hline Characteristic & ALND group (n=9) & SLNB group (n=16) & P-value \\
\hline Median age (year) & 66 & 64.5 & 0.6 \\
\hline Tumor type & & & 0.25 \\
\hline IDC & 8 & 13 & \\
\hline ILC & 1 & 1 & \\
\hline Other & 0 & 2 & \\
\hline Tumor location & & & 0.92 \\
\hline Lateral or medial & 1 & 2 & \\
\hline Central & 8 & 14 & \\
\hline Median tumor size (mm) & 27 & 19 & 0.004 \\
\hline Axillary nodal status & & & 0.65 \\
\hline Negative & 3 & 4 & \\
\hline Positive & 6 & 12 & \\
\hline Axillary ultrasound & 5 & 12 & \\
\hline Tumor grade & & & 0.053 \\
\hline I & 1 & 2 & \\
\hline II & 3 & 11 & \\
\hline III & 5 & 3 & \\
\hline Estrogen receptor status & & 0 & \\
\hline Positive & 7 & 15 & \\
\hline Negative & 2 & 1 & \\
\hline HER-2 receptor status & & 0.24 \\
\hline Positive & 1 & 16 & \\
\hline Negative & 8 & & \\
\hline
\end{tabular}

ALND: axillary lymph node dissection; HER-2: human epidermal growth factor receptor 2; IDC: invasive ductal carcinoma; ILC: invasive lobular carcinoma; mm: millimeter; n: number; SLNB: sentinel lymph node biopsy

4.3.1 Male patients undergoing immediate ALND operation for breast cancer $(n=9)$

The average age of the ALND group male patients was 66 years (range 48-82 years). All patients underwent mastectomy. Tumor location was central in the majority of patients, $(\mathrm{n}=8)$ and lower upper quadrant $(\mathrm{n}=1)$ in the remainder. The primary tumors ranged in size from 1.7 to $6 \mathrm{~cm}$ (average $2.7 \mathrm{~cm}$ ). Four of the patients had large tumors: one measuring $4 \mathrm{~cm}$ and three measuring $6 \mathrm{~cm}$. The axilla was clinically positive in two cases. Preoperative AXUS 
was used in 5 patients (55\%) and it showed pathologic lymph nodes in 2 cases. There was no axillary metastasis in 3 cases (33\%). The therapy used is summarized in Table 6.

Table 6 Summary of treatment of male breast cancers

\begin{tabular}{|l|l|l|}
\hline Characteristic & ALND group $(\mathrm{n}=9)$ & SLNB group $(\mathrm{n}=16)$ \\
\hline Type of the operation & & \\
\hline Mastectomy+ALND & 9 & 0 \\
\hline BCS+SLNB+D-ALND & 0 & 1 \\
\hline Mastectomy+SLNB & 0 & 4 \\
\hline Mastectomy+SLNB+I-ALND & & 8 \\
\hline Mastectomy+SLNB+D-ALND & 0 & 3 \\
\hline ChT & 5 & 8 \\
\hline HT & 8 & 15 \\
\hline WBI & 3 & 3 \\
\hline WBI+RRT & 6 & 8 \\
\hline
\end{tabular}

ALND: axillary lymph node dissection; BCS: breast conserving surgery; ChT: chemotherapy; D-ALND: delayed completion axillary lymph node dissection; HT: hormonal therapy; I-ALND: immediate completion axillary lymph node dissection; n:number; SLNB: sentinel lymph node biopsy; WBI: whole breast irradiation; RRT: regional radiotherapy

The median follow-up in this group was 5 months (range 1-84). In one case, axillary lymph node metastases occurred in the opposite side two years after the initial operation, and contralateral ALND was performed. Four patients died due to distant metastases and the progression of the disease after one, three, five and seven postoperative years, respectively.

4.3.2 Male patients undergoing SLNB operation for breast cancer $(n=16)$

The average age of the SLNB group male patients was 64.5 years (range 47-76 years). Tumor location was central in the majority of patients $(\mathrm{n}=14)$, and lower outer quadrant $(\mathrm{n}=$ 2 ) in the remainder. The primary tumor ranged in size from 0.6 to $3.5 \mathrm{~cm}$ (mean $1.9 \mathrm{~cm})$. All patients had a negative axillary status on physical examination. Preoperative AXUS was used in 12 patients (75\%) and it was negative in all of them. Preoperative lymphoscintigraphy was performed in all 16 patients and revealed drainage to the axilla in 15 of them, the axilla and the internal mammary region in the remaining 1 case. Intraoperatively, at least one A-SLN was identified in all 16 patients (100\% identification rate). In one case, we found 4 macroscopically malignant SLNs by intraoperative palpation and decided for immediate 
ALND. The mean number of SLNs removed at operation was 1.5 (range 1-5), which is very much in keeping with our validation series from the nineties, where the mean number of SLNs was 1.3, the accuracy and false-negative rates were $99 \%$ and $3 \%$, respectively, with the dual labelling method [55]. One IM-SLN and one intramammary SLN were excised during the study period. In the patient with the IM-SLN identified, this lymph node was free of metastasis, but the two A-SLNs of the patients were metastatic, one had a MIC and the other a MAC. Therefore, ALND was performed and 17 further uninvolved axillary nodes removed.

In the patient with an intramammary SLN, this node contained a MIC and ALND was done with the removal of 23 lymph nodes of which one harboured a MAC. In the SLNB group, intraoperative imprint cytology of the SLN was positive in 9 cases and in these we performed immediate completion ALND. In the remaining 7 patients, the intraoperative imprint cytology was negative. In 3 of them, the final histological examination proved SLN involvement (none belonged to the MAC category), and delayed completion ALND was done. Overall, the sensitivity and specificity of the intraoperative cytology were $75 \%$ (95\% confidence intervals (CI) 47-91\%) and 100\% (95\% CI 51-100\%), respectively. The surgical and adjuvant treatments are listed in Table 6. Of the 16 cases with successful SLNB, the SLN was involved in 12 patients (75\%); 9 patients had MAC, 2 patients had MIC, and 1 patient had ITC. In the majority of successful cases, SLNs were identified by both blue dye and isotope (12 cases, $75 \%)$.

In the case of SLN ITC, we could not find NSLN involvement. In the MIC group, we found NSLN involvement in one of the 2 patients. In the MAC group, NSLN involvement was present in 4 of the 9 patients. The lymph node involvement in the ALND and the SLNB group of patients with MBC is summarized in Fig. 7. 
Figure 7 Lymph node involvement in ALND and SLNB group of patients with MBC

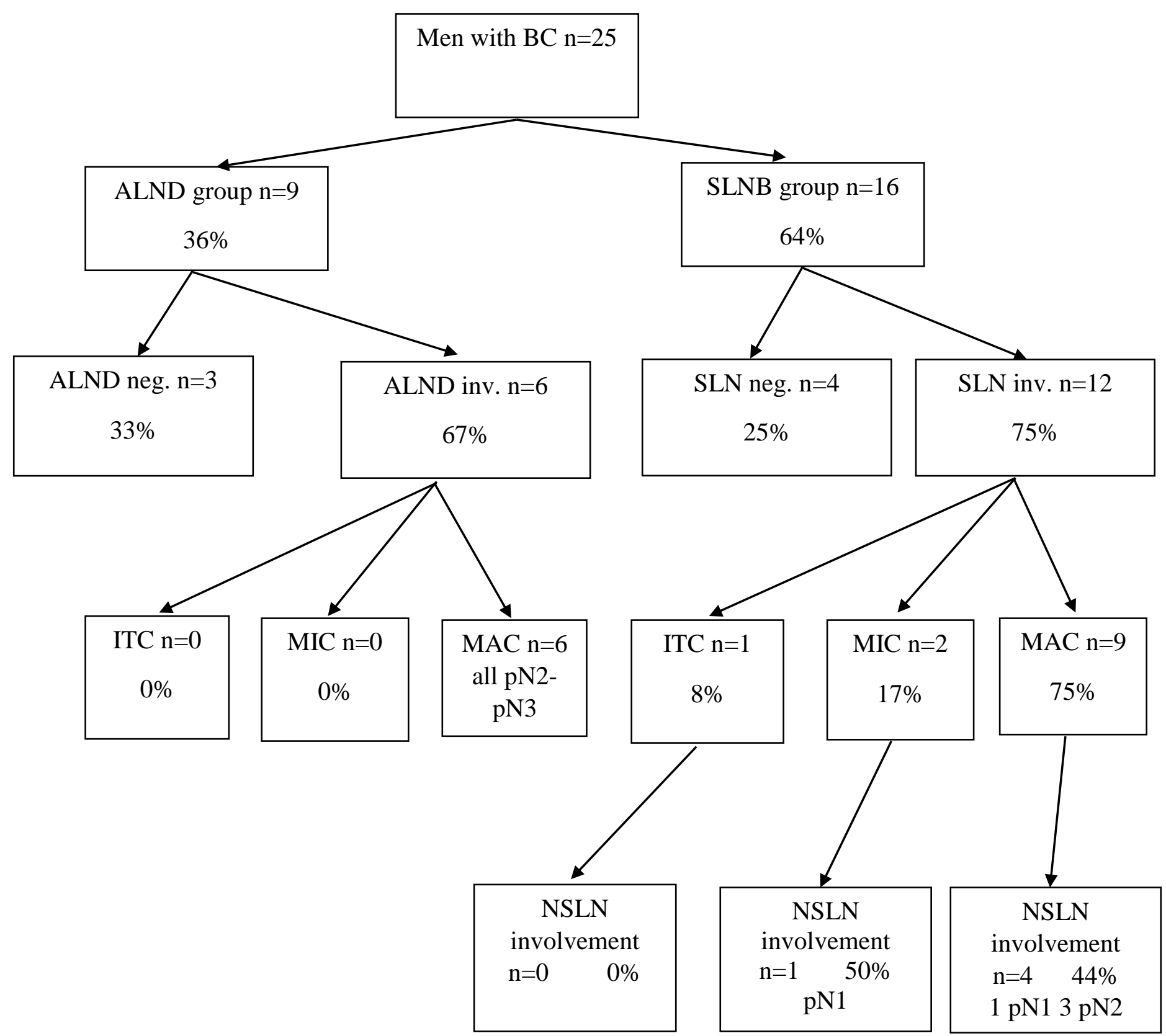

ALND: axillary lymph node dissection; BC: breast cancer; ITC: isolated tumor cells; inv: involvement; MAC: macrometastases; MBC: male breast cancer; MIC: micrometastases; n: number; neg: negative; NSLN: non sentinel lymph node; SLN: sentinel lymph node; SLNB: sentinel lymph node biopsy 


\subsubsection{Follow-up data}

The median follow-up time in the SLNB group was 68 (range:6-137) month. None of the patients who underwent SLNB alone had an axillary recurrence during this time. Five of the 16 SLNB patients of this study died, one of distant metastases of breast cancer in the lung five years after the operation, and four of unrelated causes (pneumonia and cardiorespiratory insufficiency 3, 7, 7 and 9 years after the operation, respectively). The median follow-up time for all 25 patients was 48 (range: 1-140) months.

Finally, ALND was performed in 21 patients. Five of these 21 patients had lymphedema $(24 \%)$, appearing after $1(\mathrm{n}=1), 1.5(\mathrm{n}=2)$ and $2(\mathrm{n}=2)$ years after the operation. In 3 cases, the lymphedema receded significantly after one year of physiotherapy. A total of 9 patients have died. Out of the surviving 16 patients, 15 have answered a postoperative questionnaire about the subjective aspects of the disease. The most interesting finding was that $13(87 \%)$ out of the 15 patients had no previous knowledge of the existence of MBC. Two patients had a positive family history: one's daughter and another's sister had breast cancer.

The patients were most afraid of surgery and chemotherapy. The 4 patients who had undergone SLNB only did not complain of any motoric or sensorial problems on the operated side (arm, hand). Nine of the responding patients were in the ALND group. Eight of them complained of minor (5) or moderate (3) motoric or sensorial problems on the operated side (arm, hand). Twelve of the questioned patients (80\%) are seriously worried about a possible relapse of the disease and are happy about being under follow-up care having regular check ups done.

4.4 Regional disease control in selected patients with sentinel lymph node involvement and omission of axillary lymph node dissection.

Between October 2000 and December 2012, 111 patients with demonstrated SLN involvement did not undergo an ALND and had at least 12 months of follow-up. The characteristics of the patients are summarized in Table 7. 
Table 7 Basic characteristics of the patients analyzed

\begin{tabular}{|l|l|}
\hline Characteristic & \\
\hline Mean age (year) & 60.5 \\
\hline Mean invasive tumor size (mm) & 16 \\
\hline pT1mic & 1 \\
\hline pT1a & 3 \\
\hline pT1b & 15 \\
\hline pT1c & 57 \\
\hline pT2 & 32 \\
\hline pT3 & 3 \\
\hline Tumor Grade & \\
\hline I & 21 \\
\hline II & 46 \\
\hline III & 44 \\
\hline ER-positive & 92 \\
\hline ER-negative & 19 \\
\hline PgR-positive & 81 \\
\hline PgR-negative & 30 \\
\hline HER-2-positive & 10 \\
\hline HER-2-negative & 101 \\
\hline LVI present & 19 \\
\hline LVI absent & 92 \\
\hline SLN ITC & 76 \\
\hline SLN MIC & 33 \\
\hline SLN MAC & 2 \\
\hline
\end{tabular}

ER: estrogen receptor; HER-2: human epidermal growth factor receptor 2; ITC: isolated tumor cell/cluster; LVI: lymphovascular invasion; MAC: macrometastasis; MIC: micrometastasis; mm: millimeter; PgR: progesterone receptor; SLN: sentinel lymph node

The majority of the patients had only ITC involvement of the SLNs, but $30 \%$ had MIC and 2 patients had metastasis larger than $2 \mathrm{~mm}$. All patients undergoing breast conserving surgery had adjuvant whole breast irradiation complemented with boost irradiation when the margins were close. Axillary RT was given to 29 patients (9 with SLN ITC, 19 with SLN MIC and 1 patient with axillary MAC). Systemic therapy involved HT in 75 patients, chemotherapy in 13 patients, and their combination in 19 patients. Seven patients with human 
epidermal growth factor receptor 2 (HER-2) positive tumors also received trastuzumab as part of their adjuvant treatment. The median follow-up was 37 months (range: 12-148 months).

During this period, 6 patients died, 3 of disseminated disease with multiple distant metastases (68, 70 and 117 months after surgery, respectively), and 3 of unrelated causes (62, 90 and 90 months after surgery, respectively). All the 3 patients who died of disease had only ITC category SLN involvement. Eight further patients had breast cancer related events: 1 local breast recurrence in a patient with initial ITC involved SLN, managed surgically with repeated SLNB and 2 negative SLNs, and 7 distant metastases (bone 3, lung 1, lung and liver with or without bone 2, cerebellum 1). Of the latter patients with distant metastasis, the SLN originally harboured ITCs $(n=3)$, MICs $(n=3)$ and MACs $(n=1)$. No axillary regional recurrence was detected in any of the 111 patients. The disease free survival (DFS), overall survival (OS) and breast cancer specific survival (BCSS) curves based on the Kaplan-Meier estimates are shown in Fig. 8.

The 5-year estimates for DFS, OS and BCSS were 85.7\% (standard error, SE: 0.06), 100\% (SE: 0.0) and 100\% (SE: 0.0), respectively.

The nomogram based risks of NSLN involvement in relation to the follow-up events are shown in Table 8.

The nomograms predict for further nodal involvement beyond the SLN, but since there were no regional recurrences, local and distant relapses were analyzed in this setting. There was no significant difference in the rate of relapse in patients classified as having a high or a low risk of NSLN metastasis, independently of the nomogram or predictive tool used. 

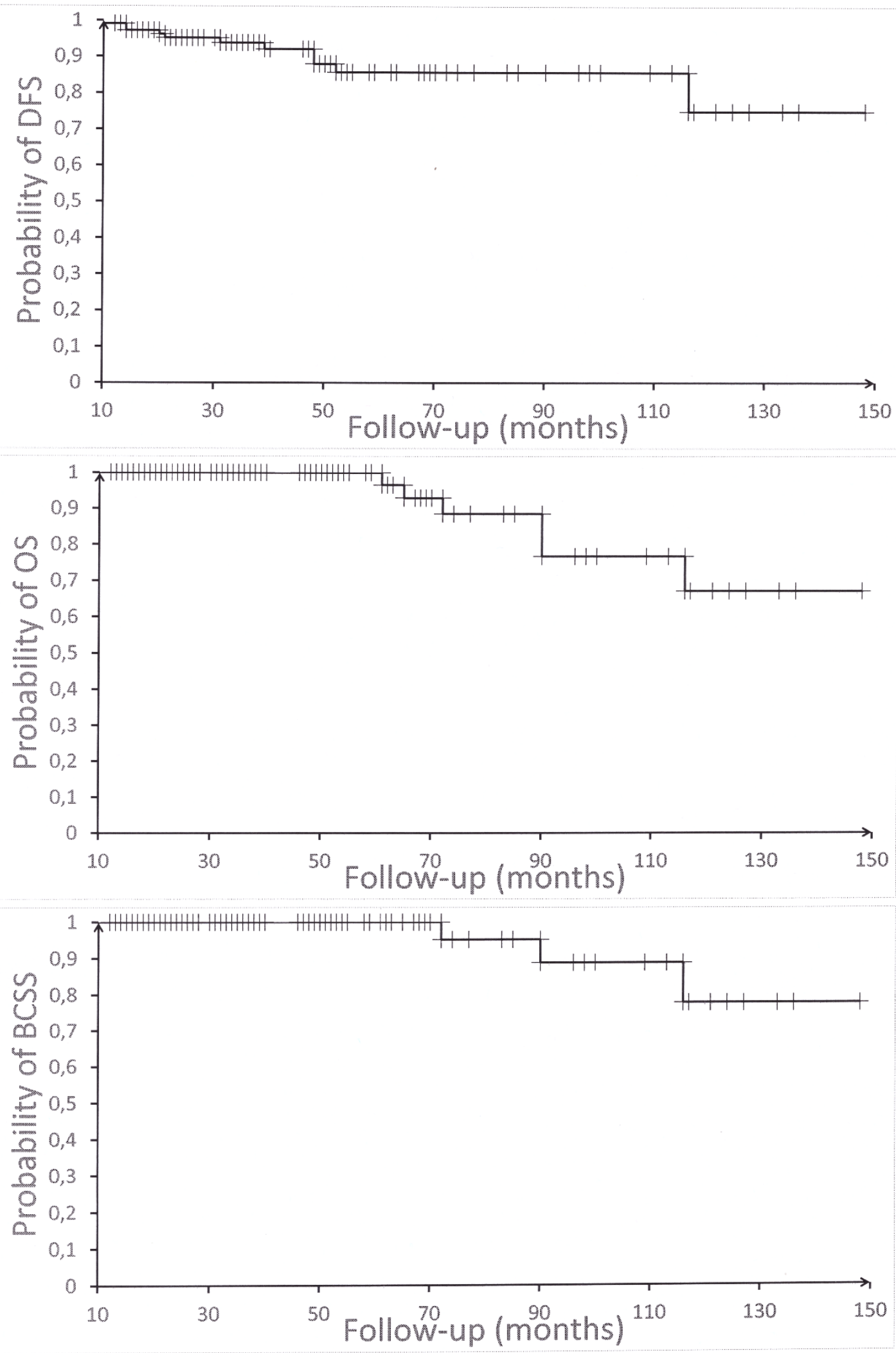

Figure 8 Kaplan-Meier survival curves for the study population

DFS: Disease free survival; OS: Overall survival; BCSS: Breast cancer specific survival 
Table 8 Distribution of patients with low volume metastatic SLN involvement according to their risk of NSLN metastasis based on the prediction by different predictive tools

\begin{tabular}{|l|l|l|l|}
\hline Nomogram & Low risk $(\leq 10 \%)$ & High risk $(>10 \%)$ & $\mathrm{p}^{\mathrm{a}}$ \\
\hline French 4-variable nomogram [36] & & & \\
\hline NED & 53 & 45 & \\
\hline REC & $7(11.7 \%)$ & $4(8.2 \%)$ & 0.75 \\
\hline Helsinki nomogram [37] & & & \\
\hline NED & 67 & 31 & \\
\hline REC & $6(8.2 \%)$ & $5(13.9 \%)$ & 0.50 \\
\hline French 5-variable nomogram [38] & & & \\
\hline NED & 77 & 21 & \\
\hline REC & $7(9.5 \%)$ & $4(16 \%)$ & 0.45 \\
\hline Danish risk factors based [35] ${ }^{\mathrm{b}}$ & & & \\
\hline NED & 67 & 32 & \\
\hline REC & $6(9.0 \%)$ & $4(12.5 \%)$ & 0.73 \\
\hline
\end{tabular}

NED: No evidence of disease; REC: recurrent disease. (Numbers in parentheses reflect the percentage of patients who experienced local or distant recurrence of their disease in the given risk category.)

a: Fisher exact test (two-sided); b: low risk defined as 0 or 1 risk factor and high risk defined as having $>1$ risk factors for both MIC and ITC. (For details on risk factors, see Materials and Methods). 


\section{DISCUSSION}

5.1 Selective ductectomy for the diagnosis and treatment of intraductal papillary lesions presenting with single duct discharge.

Although nipple discharge is a relatively common symptom and is usually benign in origin, it can also be a feature of intraductal carcinoma of the breast (DCIS). On the basis of previous reports, the incidence of DCIS in patients with nipple discharge varies from $1 \%$ to $16 \%[60,61]$. Ductography plays an important role in the assessment of single duct discharge, because it may visualize intraductal lesions. Although nipple discharge obtained by squeezing should be smeared and submitted for cytology in all such cases [62], this approach was not very helpful in our hands, as suspicion for malignancy (C4) was not raised in any of the patients. In lesions with associated atypia, the cytomorphologic features may overlap with those of low-grade IDC, and tissue biopsy might be considered for a definitive diagnosis [63].

Image-guided needle biopsies are generally the next step to get a diagnosis. Leah at al suggest excisional biopsy to be considered when a papillary lesion categorized as B3 is identified at percutaneous image-guided breast biopsy [11], because of the probability of associated malignancy [58], although these issues are somewhat controversial. Good sampling may allow the diagnosis of a benign lesion (B2) as papilloma [58]. Mammary ductoscopy (MD) / fiberoptic ductoscopy (FDS) is an endoscopic technique that allows direct visualization of the mammary ductal lining using submillimetre fiberoptic microendoscopes inserted through the ductal opening onto the nipple surface.

These scopes also provide working channels for insufflation, irrigation, ductal lavage, and possible therapeutic interventions. MD can be performed under local anesthesia in the office setting [64]. Although nipple discharge is an unusual presentation for DCIS, FDS with ductal lavage cytology can be a useful technique for the diagnosis of DCIS prior to surgery [65] in patients with nipple discharge. There was a wide divergence of opinions with regard to the treatment of nipple discharge in cases of suspected IP. The various methods of treatment included observation with no treatment; infraareolar incision with removal of a small area which contains the duct and the intraductal papilloma; wide wedge-shaped incision, removing the offending papilloma and several ducts; and a more radical procedure, resection of the nipple and areola complex. 
However, in the last 30 years, a more conservative approach has been accepted, stemming mainly from the studies of Haagensen in the United States of America and Atkins and Wolff in the United Kingdom [66]. These authors all recognized that patients whose discharge was due to IP were cured by the removal of the papilloma. Atkins developed microdochectomy through a small cut removal of a single duct following the circular line of the areola and Haagensen [7] used a procedure that is between Atkins' microdochectomy and the excision of the major duct performed by Urban [67].

If the discharge can be localized to a single duct, microdochectomy gives satisfactory results in younger patients with minimal or no change of the breast shape and function. SD can be considered as a variant of microdochectomy in which the surgeon removes the given duct and a small rim of surrounding breast tissue with the guidance of a vital dye (sometimes combined with radiocontrast material). MD as a new alternative in the management of intraductal proliferations offers the advantages of accurate localization of pathology, ductal lavage under direct visualization, and intraoperative guidance especially for lesions deep within the ductal system [68].

In our hospital, the general work-up of single duct discharge through the nipple includes mammography, ultrasonography, ductography and discharge cytology. Image guided FNAC or CNB are also used for cases with identifiable mass lesions. When these examination suggest intraductal proliferations (papillomas in general), SD, a conservative surgical excision of limited extent was our method of choice for diagnosing and treating the lesion behind the symptom. When malignancy was proven preoperatively, BCS with the ROLL technique or mastectomy with SLNB were advocated. In six cases, malignancy was discovered in the surgical specimens removed by SD and initiated a second operation in all but one patient who had a mastectomy in a third step.

Breast papillomas may be either solitary or multiple. Solitary papillomas are usually found in a subareolar location within the larger ducts, and more than half of the patients present with spontaneous nipple discharge. In contrast, multiple papillomas usually arise within the terminal duct lobular units and are most frequently peripheral in location. These patients rarely present with nipple discharge [69]. Some studies have shown an increased potential for malignancy associated with multiple (peripheral) papillomas compared to solitary (central) papillomas $[7,70,71]$. The B3 diagnostic category comprises a variety of lesions, including papillary lesions which have a lower rate of associated malignancy than the B4 (suspicious for malignancy) category, but this rate is still up to 25\% [58]. 
Histopathologically, papillary lesions also comprise a variety of lesions which are classified into different diagnostic entities [72].

Benign papillomas, hyperplastic rather than neoplastic lesions, are characterized by the presence of a dual population of luminal epithelial and myoepithelial cells both at the periphery and in the papillary areas. These were the most frequent in our series. Papillary DCIS is relatively rare in its pure form, but can be admixed with other patterns of DCIS. It is characterized by the absence of myoepithelium in the papillary projections, but its presence at the periphery of the involved duct. No such lesion was encountered in our study. Invasive papillary carcinomas retain the papillary architecture, but have no myoepithelial component.

There are also specific lesions like the encapsulated papillary carcinoma (also known as intracystic or encysted papillary carcinoma) and the solid papillary carcinoma of which the real nature is still a matter of debate. They may represent either a form of invasive carcinoma with excellent prognosis as would suggest the total or nearly total absence of the peripheral myoepithelial layer, and very rare occasions of metastatic disease, but they may also represent specific forms of in situ carcinoma as suggested by their indolent clinical behaviour and their circumscribed structure suggesting an intraductal origin. Experts tend to classify them on the basis of the latter approach [73]. It must also be remembered that papillomas may be associated with neoplastic proliferations within the lesions themselves (giving rise to AP or papillomas with $\mathrm{ADH}$ or frank in situ carcinoma) or around the lesions. Finally, some papillary lesions may defeat current categorization guidelines [59]. No encapsulated, solid or invasive papillary carcinomas were seen in this series.

Our data suggest a 6\% (95\% CI: $3-12 \%)$ in situ or invasive malignancy rate for patients presenting with simple rather than multiple duct discharge, and a suspicion of intraductal proliferation (papilloma) on ductography. For the histopathological entity of IP (77 in this series), the rate of neoplastic changes was $7.8 \%$, with four overlapping cases having both DCIS and IP. Therefore, the clinical presentation we discuss in our series was associated with neoplastic epithelial changes in 16 cases (16\%): 2 cases without histologically identified papillary lesions, and 14 with papillomas (5 fitting in to the frames of atypical hyperplasia in the papilloma, 5 with $\mathrm{ADH}$ or lobular neoplasia around the papilloma and 4 cases associated with DCIS or invasive carcinoma).

Whether this incidence of malignancy and its predominantly low grade justifies SD for the management of single duct discharge raising the possibility of intraductal proliferations consistent with central papillomas is a matter of perception. It was felt that the answer to this 
question was positive, but on the other hand, patients with nothing more than inspissated secretion related ductal obliteration and ductectasia as final diagnosis were overtreated.

Clearly, SD is just one possible approach to manage single duct discharge with papillary lesions suspected in the background, and patients should be informed about the pros and cons of this minimally invasive intervention, the low rate of malignancy associated with this clinical setting and an informed consent should naturally be obtained. Owing to the rather uncommon association with malignant findings, a watchful waiting policy could also be a viable alternative, although this does not relieve the leading symptom of nipple discharge.

Whether surgery is needed for a disease or a symptom associated with such a low incidence of malignancy, can be questionable. However, after meeting the patients, it became clear, that nipple discharge can be very unpleasant and this minimal diagnostical operation promptly cease the symptom. Considering the possibility of the oncological overtreatment (93\% of the patients had no malignant lesion, and the importance of the five in situ carcinomas is unclear) it is very important to inform the patients about the magnitude of the risk of malignancy.

Some authors make the diagnosis with CNB, others with vacuum assisted biopsy. The treatment of these B3 risk lesions is contradictional, there are authors who suggest a surgical excision $[11,74]$, and others do not find this necessary, only in the case of papillary lesions [75]. The indication for the operations in this series was very similar, although the diagnosis of IP was not established by using $\mathrm{CNB}$, but was raised with high suspicion with ductography performed for single duct discharge after previous mammographic and US examinations.

After informing the patients about the alternatives, one option can be ductoscopy, but this is not available in some countries, including Hungary. Biopsy of the papillary lesion, if it can be visualized by mammography or US is the most followed option, but there were only four such visible lesion among our cases. Another alternative can be the radiological follow up.

5.2 Internal mammary sentinel lymph node biopsy in breast cancer. Is it indicated?

The SLN is the first lymph node to receive lymphatic drainage from a tumor, and SLNB is a minimally invasive diagnostic modality for diagnosing axillary lymph node metastases in breast cancer. Many studies on lymphatic drainage of the breast have confirmed the importance of the IM basin as a second draining route in breast cancer $[76,77]$. As a consequence, IMC lymph node dissection (IMC-LND) was part of the standard surgical 
treatment in some centers in the 1950s and 1960s. This radical surgical procedure was abandoned in the 1970s because patient outcome studies showed that radical dissection did not improve survival [1]. However, these studies have clearly shown that patients with documented IM metastases, who did not receive adjuvant therapy, had a worse prognosis [1]. Veronesi et al. found in their analysis of 1119 patients that survival was significantly affected by the presence of positive IMC nodes. Ten-year survival varied between $80 \%$ in patients with axillary and IMC negative nodes, $55 \%$ in axillary positive and IMC negative nodes, 53 $\%$ in IMC positive and axillary negative patients and $30 \%$ in patients with both axillary and IMC positive nodes [78].

Since the introduction of SLNB, there has been a renewed interest in the IM-SLNs. As a consequence, IM-SLNB can refine staging in breast cancer patients and offers the possibility of providing tailored treatment in case of proven metastases to the IMC. Some authors have found a correlation between the location of the tumor and the visualized IMSLN. The proportion of patients in whom the IM-SLN could be visualized was found to be higher in patients with a tumor in the medial or central part of the breast, compared to those with a tumor in the lateral part of the breast $[1,19,78]$.

Other authors have not found such an association [79, 80]. In keeping with the unpredictability of lymphatic drainage on the basis of tumor location, this series demonstrated IM drainage in more lateral tumors than medial or central tumors. The higher rate of IM drainage in medial tumors may reflect their lower overall frequency compared to lateral tumors. The rate of identification of SLNs in the IM region is lower than in the case of ASLNB [22]. The success rate of A-SLNB in the literature is between 94-97\%, compared to the success rate of $63-88 \%$ of IM-SLNB $[1,78,80]$. There are two main reasons for this. Firstly, IM-SLNB is not performed routinely, as opposed to A-SLNB, because many breast surgeons have concerns about the rate of complications of the procedure, due to the lack of technical expertise and familiarity with the route of access.

Secondly, it is difficult to compare the results of the different studies. US-guided intraor peritumoral tracer administration followed by lymphoscintigraphy (draining via the perforating lymphatic system) has a higher rate of IMC drainage than subareolar or subdermal injections using the superficial lymphatic system [81]. It may also be hypothesized that a peritumoral injection more accurately demonstrates the true lymphatic drainage of the tumor than an injection given away from the tumor site in the skin or around the areola [81], despite the fact that most of the time the breast can be and is viewed as a single organ with a unique drainage independently of tumor location [82]. 
Because of these issues, the reported rates of IMC drainage on lymphoscintigraphy vary greatly, from $<2 \%$ to $38 \%$ of all breast tumors [83]. The proportion of patients with IMC drainage reported here $(5.4 \%)$ is also an underestimate of all patients with this phenomenon, because the universal intraparenchymal radiotracer administration used in the first part of the study period was replaced by the use of this administration route only for non-palpable tumors having a smaller chance of nodal involvement. This caveat should be kept in mind, but the data did not allow a better approach of the rate of IMC drainage, and the study concentrated more on the IM-SLNB and its implications in patients with a visualized drainage to this region, rather than the drainage itself.

In our series the success rate of A-SLNB was $96 \%$ and that of IM-SLNB was $93 \%$. The latter high rate may be a consequence of the fact that the procedure was first introduced by a breast and thoracic surgeon (Gábor Boross), and most operations were performed by experienced breast surgeons.

The number of axillary nodes involved is also an important prognostic information [84] and this may hold true for the number of metastatic IMC lymph nodes too. The overall risk of IM-SLN metastasis in breast cancer patients is well known and reported to be $18-33 \%$. Metastases exclusively situated in the IM node, without concurrent axillary metastases, occur in $2-11 \%$ of patients [85]. A larger axillary metastatic load may represent a higher risk of IMC metastasis [1], and the total number of involved nodes in the two regions together may likewise be important from a prognostic aspect, but this is currently very difficult to assess, as IMC-LND is not part of the standard treatment of breast carcinoma [22]. In our study, no significant differences were found between patients with and without IM-SLN involvement in terms of age, tumor location, tumor size, axillary involvement, tumor grade or ER status.

A possible role of nodal positivity detected by IM-SLNB may be the indication of more aggressive systemic treatment in axillary node-positive patients. Adjuvant locoregional RT has proven to be beneficial after mastectomy [86-88], but the contribution of radiation to the IMC to improve survival and recurrence rates is still unclear [89-92]. Although RT of the parasternal region does not seem to improve the survival [93], the value of this treatment in IM-SLN-positive patients detected by IM-SLNB should also be assessed in future studies [22].

The EORTC 22922/10925 trial has been devised to investigate the potential survival benefit and toxicity of elective irradiation of the internal mammary and medial supraclavicular (IM-MS) nodes. It is currently evaluating the impact of IM-MS irradiation on long term disease-free and overall survival in breast cancer patients with centrally or medially 
located tumors. Only lung (fibrosis; dyspnoea; pneumonitis; any lung toxicities) but not cardiac toxicity increased significantly with IM-MS treatment. IM-MS irradiation seems well tolerated and does not significantly impair performance status at 3 years. A follow-up period of at least 10 years is needed to determine whether cardiac toxicity is increased after such radiotherapy [94]. As for today, there is insufficient data to determine a positive effect of parasternal RT on survival in patients with proven IM metastases.

Axillary adjuvant RT is beneficial in terms of locoregional control in high-risk subgroups, such as patients with more than 3 axillary metastases [94]. As a consequence, by extrapolation, it could be reasonable to add parasternal RT to the treatment regimen in patients with tumor-positive IM-SLNs, if their metastatic volume is higher, e.g. in case of MAC or multiple nodal involvement. In contrast to adjuvant RT to the IMC, systemic treatment of high-risk breast cancer patients has a proven survival benefit [95]. Its administration is based on a set of prognostic and predictive factors, of which nodal status is only one, even if considered among the most important ones.

The systemic treatment strategy was rarely influenced by IM metastases in this series of patients. Due to axillary metastases and unfavourable primary tumor characteristics, a lot of patients would have already received adjuvant chemotherapy and even more of them would have had adjuvant HT. In the remaining patients, old age and negative ER status further limited the proportion of patients who would have received adjuvant systemic therapy based on IM-SLN metastases. Dutch national guidelines on the treatment of breast cancer do not recommend routine biopsy of the IM-SLNs.

Adjuvant chemotherapeutic treatment and IMC irradiation is however indicated when a tumor-positive IMC lymph node is found [96]. IM-SLNB may be associated with some additional morbidity in about $3-10 \%$ of the cases, according to the literature: pleural lesions or injury of the IM artery $[1,19,78]$. Recovery is usually uneventful in the case of pleural lesions, after simple vacuum drainage. The injury of the IM artery poses more serious challenges. In our study we recognized minor complications in 8 cases (9.6\%) and one major complication (1.2\%) also occurred. Recovery was uneventful in both the minor and the major complication group. The literature is rather inconclusive as concerns the recommendation of IM-SLNB. Table 9 shows details and main conclusions of larger IM-SLNB studies.

On the basis of recent publications, arguments for performing IM-SLNB are the following:

It helps the correct staging of patients with breast cancer [22]. IM-SLN involvement is a prognostic factor [22] and an adverse prognostic indicator of increased distant metastases 
and reduced survival, even in the absence of axillary disease [78]. In case of IM-SLN-positive patients, the treatment can be altered (chemo- or radiotherapy) [22]. Studies evaluating the effect of the IM-SLNB on the treatment strategy in patients with an IMC drainage pattern report a change of treatment in 2-9\% [94, 100]. Since adjuvant systemic treatment in this small but substantial patient group is likely to improve prognosis, authors of these studies recommend routine biopsy of IM-SLNs.

There are also arguments against IM-SLNB, and these are listed as follows:

IM-SLN metastases occur only in a small proportion of patients undergoing SLNB (1.4-4.6\%) [22, 100], (although they have a higher rate of occurrence (18-33\%) [55] in patients having IMC drainage and IM-SLNB. US-guided intra- or peritumoral tracer administration demonstrates a higher rate of IMC drainage than subareolar or subdermal injections which are often used for A-SLNB. Overall, isolated IM-SLN involvement is rare $(2-9 \%)[22,94,100]$. If the A-SLNs are negative, then IM-SLNs are also negative in $41.2 \%-$ $56.6 \%$ [22]. Although there could be new indications for IMC RT if both A-SLNs and IMSLNs are positive (13.2-22.7\%) [22] and for chemotherapy if A-SLNs are negative but an IM-SLN is positive $(2.1-9 \%)$, the IM node status resulted in a change of the adjuvant treatment plans in only $3.4 \%$ of the patients [1].

Some authors have found predictive factors of IMC positivity, including age $<35$ years, grade III histology and lymphatic vascular invasion [78], that would make IM-SLNB less important.

The impact of IM-SLNB on altering adjuvant systemic therapy was relatively small in our series. We have found IM-SLN involvement in 14 cases, which represents $18 \%$ of the patients who underwent IM-SLNB, but in 7 cases, only ITC were found, and these are not considered metastasis at present [101]. Neither ITC, nor MIC nor MAC of the IM-SLN has lead to further surgical therapy. Micrometastases in A-SLNs or IM-SLNs were not an indication for adjuvant chemotherapy.

In our series, only 1 patient received RT to the IMC, and a new indication for chemotherapy was also established in only 1 patient because of MAC of the IM-SLN. Therefore in our series consisting of 77 patients, only 2 of the IM-SLNB patients $(2.6 \%)$ had therapeutic consequences. As for today, there are insufficient data to determine a positive effect of parasternal RT on survival in patients with proven IM metastases. On the other hand, IM-SLNB may be associated with some additional morbidity: pleural lesions or injury of the IM artery. 
Table 9 Details and main conclusions of larger IM-SLNB studies

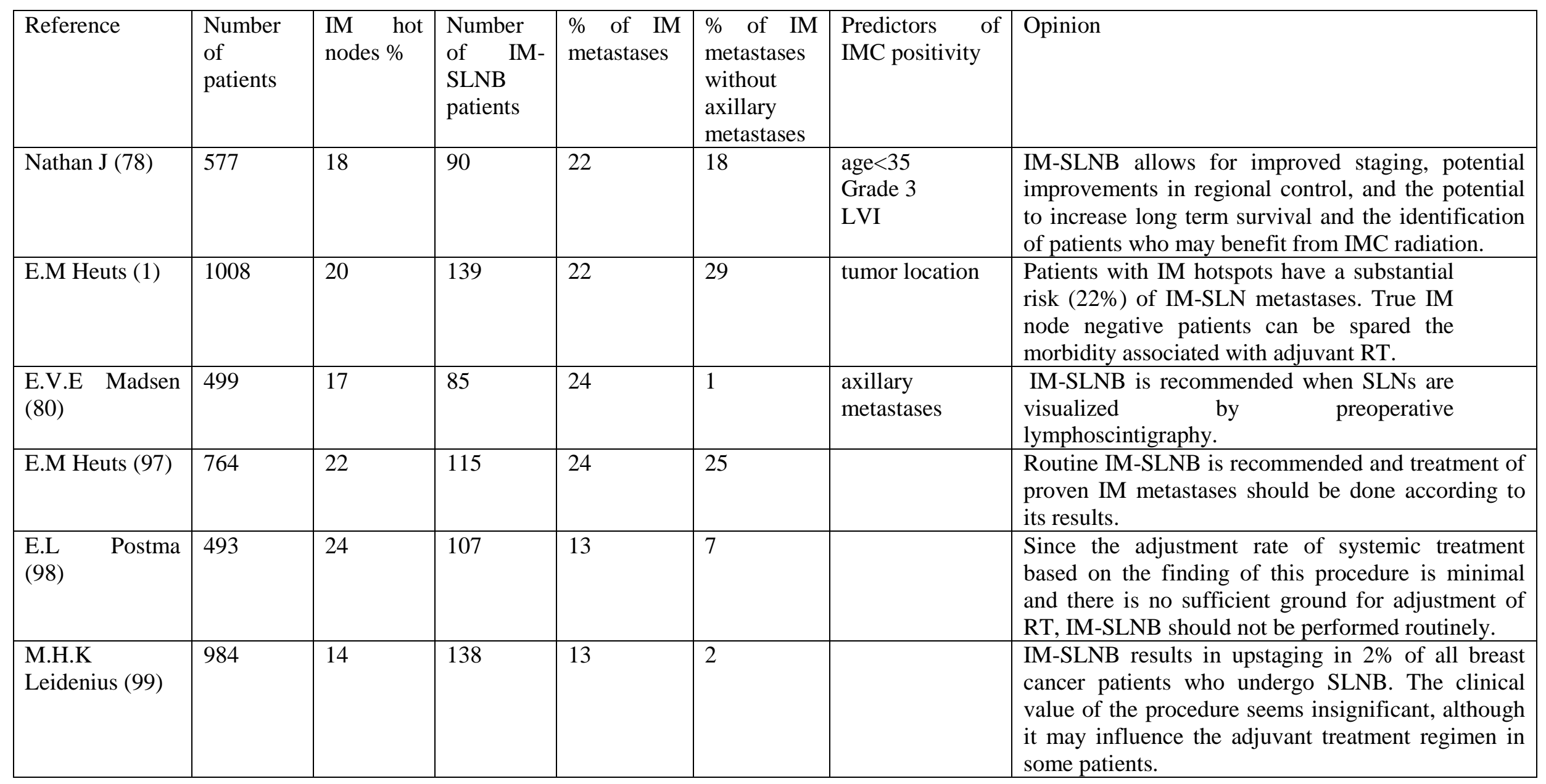

IM: Internal mammary; IMC: internal mammary chain; IM-SLN: internal mammary sentinel lymph node; IM-SLNB: internal mammary sentinel lymph node biopsy; LVI: lymphovascular invasion; RT: radiotherapy; SLN: sentinel lymph node; SLNB: sentinel lymph node biopsy 
5.3 The role of sentinel node biopsy in male breast cancer

Because of the lack and uselessness of general screening in this sex, MBC is rarely detected mammographically. It mostly manifests as a palpable mass, at a later stage and a larger tumor size. The majority of MBC patients undergo mastectomy because of the small breast size and subareolar location of most malignancies [102]. Because of the low incidence, treatment for breast cancer in men has been extrapolated from the experience of treatment of breast cancer in women, without the benefits of randomized trials. ALND is associated with a number of complications, including lymphedema, axillary paresthesia and decreased range of motion of the shoulder and arm. SLNB permits removal of a smaller number of lymph nodes that can be subjected to a more detailed pathologic examination, resulting in improved staging of the regional lymph nodes [103]. Randomized trials have also demonstrated decreased morbidity with SLNB compared to ALND, and SLNB has rapidly been incorporated into the treatment of women with early-stage breast cancer [104-110].

The first SLNB in MBC was reported in 1999 by Hill and colleagues [46] from the Memorial Sloan-Kettering Cancer Center. Since that report, its use has increased and there are several additional studies reporting on 6, 9, 16, and 18 patients [45, 47-49]. Since the experience was published in 2004, SLNB has been routinely offered to all male patients with breast cancer and clinically negative axillary nodes, according to the standard policy applied to women with breast cancer at the European Institute of Oncology, Milan, Italy [48]. Frequently, breast cancer in men is diagnosed at an advanced stage, making SLNB inappropriate, but still a considerable proportion of patients present with a clinically negative axilla, therefore making them candidates for a less invasive method of axillary staging. At the beginning of the study period, mastectomy was performed with immediate ALND, without attempting SLNB. The reasoning behind this policy was as follows: the size of tumors in males is typically larger compared to females, larger tumors are more often accompanied by lymph node metastases, and there were insufficient data on the role of SLNB in male patients. This approach was used in 9 patients.

The final histological examination of the ALND specimen proved a negative nodal status in 3 of them. One of these cases was seen in 2004, at the beginning of the examined period, before the accumulation of sufficient evidence allowing SLNB in MBC. The second patient was 82 years old, and the avoidance of a possible second axillary operation in case of a metastatic SLN arguably deviated us from SLNB. The last patient had a 4-cm-large tumor 
and had a strong clinical suspicion of axillary metastases. In our experience, 4 of 16 patients (25\%) who underwent SLNB were spared an unnecessary axillary dissection. Should SLNB been performed in all male patients with negative axillae, 3 further men could have been spared the potential morbidity of ALND, and this rate could have been 7/25. As shown in Table 5, the group treated with upfront ALND was not very much different from the one where SLNB was attempted, except for tumor size and the 2 cases where the axilla was clinically positive.

The SLNB procedure is a technically feasible and accurate method of evaluating males with clinically node-negative $\mathrm{BC}[47,111]$. If an SLN is positive for metastatic disease, complete ALND has been recommended [112]. Owing to the relatively high rate of nodal involvement, intraoperative SLN examinations are of value. The sensitivity of imprint cytology found in our small series does not seem very gratifying, but is in line with the $63 \%$ (95\% CI 57-69\%) pooled sensitivity of the method reported by a meta-analysis [113], and if only MACs are considered, the sensitivity goes up to an idealistic $100 \%$. Although the choice of intraoperative assessment should be based on local preferences and expertise [114], frozen sections seem somewhat better than imprint cytology [115], but both methods become worse with MICs. Quantitative molecular methods like one step nucleic acid amplification are probably the most sensitive methods, if one wants to detect virtually all metastases [116]. Table 10 shows details and main results of larger SLNB studies relating to MBC.

Our experience is in keeping with the data summarized in Table $\mathbf{1 0 .}$

Compared to female patients, a larger proportion of male patients $(75 \%)$ have positive nodes, but for patients with clinically negative nodes, SLNB may reduce morbidities associated with ALND.

The feed-back from the patients in our questionnaire shows that in the SLNB group patients had no motoric and sensory problems as opposed to the ALND group where a large majority complained about these, and this supports the idea that SLNB is associated with less morbidity than ALND in male patients too. A panel of the American Society of Clinical Oncology stated that "although the data are limited... it is unlikely that SLNB will be any less accurate in men than it is in women'" [118]. The cumulative evidence from previously published and the current series support this notion. In the absence of stronger evidences based on larger numbers, it seems reasonable to recommend modified radical mastectomy as the gold standard in men, in whom an SLN cannot be identified. 
Table 10 Summary of literature on male sentinel node biopsy in breast cancer

\begin{tabular}{|c|c|c|c|c|c|c|c|c|c|}
\hline Reference & $\begin{array}{l}\text { Number of } \\
\text { patients }\end{array}$ & $\begin{array}{l}\text { SLNB } \\
\text { successful \% }\end{array}$ & $\begin{array}{l}\text { SLNB } \\
\text { positive \% }\end{array}$ & $\begin{array}{l}\text { Median } \\
\text { age (year) }\end{array}$ & $\begin{array}{l}\text { Palpable } \\
\text { mass \% }\end{array}$ & $\begin{array}{l}\text { Mean } \\
\text { tumor size } \\
(\mathrm{cm})\end{array}$ & \begin{tabular}{|l|} 
Tumor \\
histology \\
(IDC) \%
\end{tabular} & $\begin{array}{l}\text { ER positive } \\
\%\end{array}$ & $\begin{array}{l}\text { Mastectomy } \\
\%\end{array}$ \\
\hline $\begin{array}{l}\text { Flynn } \\
\text { (117) }\end{array}$ & 78 & 97 & 49 & 60 & 77 & 1.9 & 83 & 98 & ni \\
\hline $\begin{array}{ll}\text { Rusby } & \text { J.E } \\
(118) & \end{array}$ & 31 & 96 & 61 & 62 & 42 & 1.9 & 84 & 100 & 81 \\
\hline $\begin{array}{l}\text { Boughey J.C } \\
\text { (111) }\end{array}$ & 30 & 100 & 37 & 62.5 & 80 & 2 & 83 & 97 & 100 \\
\hline Our results & 16 & 100 & 75 & 61 & 78 & 1,9 & 81 & 94 & 94 \\
\hline
\end{tabular}

cm: centimeter; ER: estrogen receptor; IDC: invasive ductus carcinoma; ni: no information; SLNB: sentinel lymph node biopsy 
5.4 Regional disease control in selected patients with sentinel lymph node involvement and omission of axillary lymph node dissection.

Lymph node status is still considered one of the most powerful prognostic factors in breast cancer. Besides being a qualitative prognosticator (metastatic lymph nodes or a positive nodal status versus the lack of metastases, i.e. a negative nodal status) it is also a quantitative one. A greater tumor burden in the regional lymph nodes reflects worse prognosis, and conversely, a smaller tumor burden means smaller and even questionable disadvantage in prognosis.

The involvement of NSLNs is influenced by several factors among which the size / degree of the SLN involvement is one of the most important. Low-volume SLN metastases of the micrometastatic category are associated with NSLN positivity in 10-15\% of the cases [120], a proportion which is confirmed by the data of recent clinical trials [27-29], but as highlighted in the introduction, depending on the combination of several factors, this may double or triple in a minority of patients [35-38]. In this respect, ITCs do not seem much better, as on average, they are suggested to be associated with NSLN involvement in about $12 \%$ of the cases according to a meta-analysis [121].

It must also be remembered that until recently, the distinction between ITC and MIC by pathologists was far from perfect $[122,123]$. Taking all this together, analyzing patients with SLN MIC or ITC together makes sense. Although current trends favor the omission of ALND in many patients with minimal SLN involvement including all with SLN MIC [37, 38], this approach may ignore a small minority of patients who could potentially benefit from further axillary treatment $[35,124]$. This makes follow-up studies of patients with involved SLNs but no ALND important.

One of the first studies of the kind reported no axillary recurrence for a selected group of SLN micrometastatic patients with favorable prognostic profile during a median follow-up period matching the present one [125]. Likewise, this series also included mainly patients deemed to have a low risk of further nodal involvement, including many with SLN ITC only. Unlike in other studies, some patients with omitted ALND and receiving RT to the breast following breast conservation, also got irradiation of the axillary region, which we believe to constitute an overtreatment in patients with low risk of axillary NSLN involvement. In keeping with the results of the first similar report [125], no axillary recurrence occurred 
during the follow-up period, but 11 breast cancer related events were noted, including 3 deaths from metastatic disease.

The results of clinical trials looking at the safety of omitting ALND in patients with minimal SLN involvement [27-29], also point to a very low rate of axillary recurrence after a somewhat longer median follow-up, and the occurrence of local (in breast) and systemic disease recurrence. This seems unrelated to the manifestation of recurring axillary cancer (Table 11), and also to the predicted risk of NSLN involvement on the basis of predictive tools devised for low volume SLN metastasis patients (Table 8). 
Table 11 Follow-up events of patients with SLN involvement and no ALND in published reports

\begin{tabular}{|c|c|c|c|c|c|c|c|c|}
\hline Present & 111 & $2 / 33 / 76$ & 37 & 0 & 1 & 10 & 3 & 3 \\
\hline Galimberti V[29] & 467 & $0 / 467 / 0$ & 60 & 5 & 8 & 25 & 0 & 2 \\
\hline
\end{tabular}

DOD: dead of disease, DOOC: dead of other (unrelated) causes, ITC: isolated tumor cell/cluster, MAC: macrometastasis, MIC: micrometastasis, ni: no information. (Studies listed according to length of median follow-up.) 


\section{CONCLUSIONS}

6.1

Single duct nipple discharge with ductographic findings suggestive of intraductal proliferation was associated with malignancy (most of the time in situ carcinoma) in $6 \%$ of the cases and atypical hyperplasia in further $10 \%$ of the cases. For such a low risk and generally low grade of malignancy, simple follow-up could be offered from a surgical and an oncological point of view, but in some cases, considering the patients' request to get rid of the symptoms, SD could be applied. Whenever associated mass lesions or microcalcifications are identified, these require separate work-up, including non-operative guided biopsies or surgical excisions for both high risk lesions on non-operative diagnostics and lesions with inconclusive non-operative assessment. Our retrospective analysis suggests that SD is well tolerated, has no major complications and might be a realistic diagnostic and therapeutic approach in the clinical situations described above.

6.2

Based on our own series and information from the literature, we conclude that the indication for an IM-SLNB procedure is very limited, and its routine use should not be recommended — which is also in agreement with the latest Hungarian guidelines [126]. A failure to identify an A-SLN is an indication for ALND in general, but it is felt that if there is no lymphatic drainage towards the axilla on lymphoscintigraphy, and even vital dye guided A-SLNB fails to identify an A-SLN, but an IM-SLN is visualized on the lymphoscintigram, IM-SLNB could be considered for nodal staging, and the omission of ALND could also be envisaged. In the studied setting, the data point more to abandoning routine IM-SLNB in patients with IMC drainage and potentially restricting its use to a very small subset of patients.

6.3

We conclude that SLN operations in male patients with clinically node-negative BC are feasible and accurate and appear to be an appropriate alternative to routine ALND. Intraoperative evaluation of the SLN should be strongly considered in the surgical management of MBC patients.

6.4

The presented retrospective data suggest that omitting ALND in patients with low volume SLN metastasis may be a safe procedure, and support the observation that systemic disease recurrence may not be associated with axillary recurrence or the risk of NSLN involvement predicted by nomograms. 


\section{ACKNOWLEDGEMENTS}

I thank

- my supervisor, Dr Gábor Cserni, Professor at the Department of Pathology, University of Szeged and head of the Department of Pathology, Bács-Kiskun County Teaching Hospital, Kecskemét for his time, support and the scientific guidance of my work;

- Dr. Mihály Svébis, principal director of Bács-Kiskun County Teaching Hospital, for his support of my work;

- the general support of Drs József Pap-Szekeres and Gábor Pajkos, heads of the Departments of Surgery and Oncology at the Bács-Kiskun County Teaching Hospital, respectively for providing me excellent conditions to carry out the presented works;

- the help of Gábor Fejes, Department of Informatics;

- Drs. Gábor Boross, László Markó, Éva Ambrózay, Mária Rajtár, Gabriella Gábor, Rita Bori, Csaba Polgár and Aida Sirbu, Tünde Gyapjas, Józsefné Ritka, Andrea Domokos, Zsolt Kárpáti who also helped this thesis to be born;

at last, but not least, my family for encouraging and supporting me. 


\section{REFERENCES}

1. Heuts EM, van der Ent FW, Hulsewe KWE et al. Internal mammary lymph drainage and sentinel node biopsy in breast cancer - A study on 1008 patients. Eur J Surg Oncol 2009; 35:252-257.

2. Tabár L, Duffy SW, Neuman HB. The natural history of breast carcinoma: what have we learned from screening? Cancer 1999; 86: 449-462.

3. Cady B, Stone MD, Schuler JG et al. The new era in breast cancer. Invasion, size, and nodal involvement dramatically decreasing as a result of mammographic screening. Arch Surg 1996; 131: 301-308.

4. Cserni G. The sentinel lymph node theory in breast cancer. (Az örszemnyirokcsomók elmélete emlörákban) Magyar Tudomány 2004; 7: 718-722. (Hungarian)

5. Greif F, Sharon E, Shechtman I et al. Carcinoma within solitary ductal papilloma of the breast. EJSO 2010; 36:384-386.

6. Maxwell AJ. Ultrasound guided vacuum-assisted excision of breast papillomas: review of 6-years experience. Clin Radiol 2009; 64:801-806.

7. Haagensen CD. Diseases of the Breast, 3rd ed, Solitary intraductal papilloma. Philadelphia: WB Saunders. 1986; pp 137-175

8. Hou MF, Huang TJ, Liu GC. The diagnostic value of galactography in patients with nipple discharge. Clin Imaging 2005; 25:74-81.

9. Bruce L, Daniel R, Gardner W et al. Magnetic resonance imaging of intraductal papilloma of the breast. Mag Reson Im 2003; 21:887-892.

10. Hünerbein M, Dubowy A, Raubach M et al. Gradient index ductoscopy and intraductal biopsy of intraductal breast lesions. Am J Surg 2007; 194:511-514.

11. Leah S, Feldman SM, Balassanian R et al. Association of breast cancer with papillary lesions identified at percutaneous image-guided breast biopsy. Am J Surg 2004; 188:365-370.

12. Veronesi U, Viale G, Paganelli G et al. Sentinel lymph node biopsy in breast cancer: ten-year results of a randomized controlled study. Ann Surg 2010; 251:595-600.

13. Zavagno G, De Salvo GL, Scalco G et al. A randomized clinical trial on sentinel lymph node biopsy versus axillary lymph node dissection in breast cancer: results of the Sentinella/GIVOM Trial. Ann Surg 2008; 247: 207-213.

14. Andersson $\mathrm{Y}$, de Boniface J, Jönsson PE et al. Axillary recurrence rate 5 years after negative sentinel node biopsy for breast cancer. Br J Surg 2012; 99: 226-231.

15. Hunt KK, Ballman KV, McCall LM et al. Factors associated with local-regional recurrence after a negative sentinel node dissection: results of the ACOSOG Z0010 trial. Ann Surg 2012; 256:428-436.

16. Krag DN, Anderson SJ, Julian TB et al. Sentinel-lymph-node resection compared with conventional axillary-lymph-node dissection in clinically node-negative patients with breast cancer: overall survival findings from the NSABP B-32 randomised phase 3 trial. Lancet Oncol 2010; 11:927933.

17. Uren RF, Howman-Giles RB, Thompson JF et al. Mammary lymphoscintigraphy in breast cancer. J Nucl Med 1995; 36:1775-1780.

18. Lamonica D, Edge SB, Hurd T et al (2003) Mammographic and clinical predictors of drainage patterns in breast lymphoscintigrams obtained during sentinel node procedures. Clin Nucl Med 2003; 28:558-564.

19. Van der Ent FW, Kengen RA, van der Pol HA et al. Halsted revisited: internal mammary sentinel lymph node biopsy in breast cancer. Ann Surg 2001; 234:79-84.

20. Estourgie SH, Nieweg OE, Valdes Olmos RA et al. Lymphatic drainage patterns from the breast. Ann Surg 2004; 239:232-237.

21. Estourgie SH, Tanis PJ, Nieweg OE et al. Should the hunt for internal mammary chain sentinel nodes begin? An evaluation of 150 breast cancer patients. Ann Surg Oncol 2003; 10:935-941. 
22. Cserni G, Pap-Szekeres J. Internal mammary lymph nodes and sentinel node biopsy in breast cancer. Surg Oncol 2001; 10: 25-33.

23. Veronesi U, Cascinelli N, Bufalino R et al. Risk of internal mammary lymph node metastases and its relevance on prognosis of breast cancer patients. Ann Surg 1983; 198: 681-684.

24. Cserni G, Burzykowski T, Vinh-Hung V et al. Axillary sentinel node and tumorrelated factors associated with non-sentinel node involvement in breast cancer. Jpn J Clin Oncol 2004; 34:519-524.

25. Viale G, Maiorano E, Pruneri G et al. Predicting the risk for additional axillary metastases in patients with breast carcinoma and positive sentinel lymph node biopsy. Ann Surg. 2005; 241:319-325. 26. Veronesi U, Viale G, Paganelli G et al. Sentinel lymph node biopsy in breast cancer: ten-year results of a randomized controlled study. Ann Surg 2010; 251:595-600.

27. Giuliano AE, McCall L, Beitsch $\mathrm{P}$ et al. Locoregional recurrence after sentinel lymph node dissection with or without axillary dissection in patients with sentinel lymph node metastases: the American College of Surgeons Oncology Group Z0011 randomized trial. Ann Surg 2010; 252:426432.

28. Solá M, Alberro JA, Fraile $M$ et al. Complete axillary lymph node dissection versus clinical follow-up in breast cancer patients with sentinel node micrometastasis: final results from the multicenter clinical trial AATRM 048/13/2000. Ann Surg Oncol 2013; 20:120-127.

29. Galimberti V, Cole BF, Zurrida $S$ et al. Axillary dissection versus no axillary dissection in patients with sentinel-node micrometastases (IBCSG 23-01): a phase 3 randomised controlled trial. Lancet Oncol 2013; 14:297-305.

30. Park J, Fey JV, Naik AM et al. A declining rate of completion axillary dissection in sentinel lymph node-positive breast cancer patients is associated with the use of a multivariate nomogram. Ann Surg 2007; 245:462-468.

31. Bilimoria KY, Bentrem DJ, Hansen NM et al. Comparison of sentinel lymph node biopsy alone and completion axillary lymph node dissection for node-positive breast cancer. J. Clin. Oncol 2009; 27:2946-2953.

32. Wasif N, Maggard MA, Ko CY et al. Underuse of axillary dissection for the management of sentinel node micrometastases in breast cancer. Arch Surg 2010; 145:161-166.

33. Goldhirsch A, Wood WC, Coates AS et al. Strategies for subtypes - dealing with the diversity of breast cancer: highlights of the St. Gallen International Expert Consensus on the Primary Therapy of Early Breast Cancer 2011. Ann Oncol 2011; 22:1736-1747.

34. AGO, DGS, SGS, ÖGS, Panelists, Executive Board Members. German, Austrian and Swiss consensus conference on the diagnosis and local treatment of the axilla in breast cancer. Eur J Cancer 2013; 49:2277-2283.

35. Tvedskov TF, Jensen MB, Lisse IM et al. High risk of non-sentinel node metastases in a group of breast cancer patients with micrometastases in the sentinel node. Int J Cancer 2012; 131:2367-2375.

36. Meretoja TJ, Strien L, Heikkilä PS et al. A simple nomogram to evaluate the risk of non-sentinel node metastases in breast cancer patients with minimal sentinel node involvement. Ann Surg Oncol 2012; 19:567-576.

37. Houvenaeghel G, Nos C, Giard S et al. A nomogram predictive of non-sentinel lymph node involvement in breast cancer patients with a sentinel lymph node micrometastasis. Eur J Surg Oncol 2009; 35:690-695.

38. Houvenaeghel G, Bannier M, Nos C et al. Non sentinel node involvement prediction for sentinel node micrometastases in breast cancer: nomogram validation and comparison with other models. Breast 2012; 21:204-209.

39. Grabau D, Dihge L, Ferno M et al. Completion axillary dissection can safely be omitted in screen detected breast cancer patients with micrometastases. A decade's experience from a single institution. EJSO 2013; 39:601-607.

40. Crichlow RW, Galt SW. Male breast cancer. Surg Clin N Am. 1990;70:1165-1177.

41. Donegan WL, Redlich PN. Breast cancer in men. Surg Clin N Am. 1996;76:343-363.

42. Fentiman IS, Fourquet A, Hortobagyi G. Male breast cancer. Lancet. 2006; 367:595-604. 
43. Gennari R, Curigliano G, Jereczec-Fossa Bet al. Male breast cancer: a special therapeutic problem. Anything new? Int J Oncol 2004; 24: 663-670.

44. Albo D, Ames FC, Hunt KK et al. Evaluation of lymph node status in male breast cancer patients: a role for sentinel lymph node biopsy. Breast Cancer Res Treat. 2003;77:9-14.

45. Port ER, Fey JV, Cody HS 3rd et al. Sentinel lymph node biopsy in patients with male breast carcinoma. Cancer 2001; 91:319-323.

46. Hill AD, Borgen PI, Cody HS 3rd. Sentinel node biopsy in male breast cancer. Eur J Surg Oncol 1999; 25:442-443.

47. Cimmino VM, Degnim AC, Sabel MS et al. Efficacy of sentinel lymph node biopsy in male breast cancer. J Surg Oncol 2004; 86:74-77.

48. De Cicco C, Baio SM, Veronesi P et al. Sentinel node biopsy in male breast cancer. Nucl Med Commun. 2004; 25:139-143.

49. Goyal A, Horgan K, Kissin M et al. ALMANAC Trialists Group, et al. Sentinel lymph node biopsy in male breast cancer patients. Eur J Surg Oncol 2004; 30: 480-483.

50. Kuenen-Boumeester V, Menke-Pluymers M, de Kanter AY et al. Ultrasound-guided fine needle aspiration cytology of axillary lymph nodes in breast cancer patients. A preoperative staging procedure. Eur J Cancer 2003; 39:170-174.

51. Sapino A, Cassoni P, Zanon E et al. Ultrasonographically guided fine-needle aspiration of axillary lymph nodes: role in breast cancer management. Br J Cancer 2003; 88:702-706.

52. Ambrózay E, Cserni G, Serényi $P$ et al. The role of axillary nodal staging during preoperative breast diagnostics. Eur J Cancer Suppl 2004; 2:92-93

53. Gennari R, Galimberti V, De Cicco C et al. Use of technetium 99m-labeled colloid albumin for preoperative and intraoperative localization of non palpable breast lesions. J Am Coll Surg 2000; 90:692-699.

54. Cserni G. Complete sectioning of axillary sentinel nodes in patients with breast cancer. Analysis of two different step sectioning and immunohistochemistry protocols in 246 patients. J Clin Pathol 2002; 55:926-931.

55. Greene FL, Page DL, Fleming ID et al. (eds) AJCC Cancer Staging Handbook New York. Springer, Berlin, 2002; p 469

56. Giordano SH, Buzdar AU, Hortobagyi GN. Breast cancer in men. Ann Intern Med. 2002;137:678687.

57. Ottini L, Palli D, Rizzo S et al. Male breast cancer. Crit Rev Oncol Hematol. 2010;73:141-155.

58. Amendoeira I, Apostolikas N, Bellocq JP et al. Quality assurance guidelines for pathology. In: Perry N, Broeders M, de Wolf C, Törnberg S, Holland R, von Karsa L (eds) European guidelines for quality assurance in breast cancer screening and diagnosis, 4th edn. European Commission, Luxemburg 2006; pp 219-311.

59. Cserni G. Benign apocrine papillary lesions of the breast lacking or virtually lacking myoepihelial cells- potential pitfalls in diagnosing malignancy. APMIS 2012; 120:249-252.

60. Leis HP Jr. Management of nipple discharge. World J Surg 1989; 13:736-742.

61. Buhl-Jorgensen SE, Fischermann K, Johansen H et al. Cancer risk in intraductal papilloma and papillomatosis. Surg Gynecol Obstet 1968; 127:1307-1312.

62. Al Sarakbi W, Worku D, Escobar PF et al. Breast papillomas: current management with a focus on a new diagnostic and therapeutic modality. International Seminars in Surgical Oncology 2006; 3:1.

63. Sneige N. Fine-needle aspiration cytology of in situ epithelial cell proliferation in the breast. Am J Clin Pathol 2000; 113:38-48.

64. Kefah M, Pedro FE, Tadaharu M. Mammary ductoscopy: current status and future prospects. EJSO 2005; 31:3-8.

65. Shen K-W, Wu J, Lu J-S et al. Fiberoptic ductoscopy for breast cancer patients with nipple discharge. Surg Endosc 2001; 15:1340-1345.

66. Atkins H, Wolff B. Discharge from the nipple. BJS 1964; 51:602-606.

67. Urban JA. Excision of the major duct system of the breast. Cancer 1963; 16:516-520. 
68. Dietz JR, Crowe JP, Grundfest $\mathrm{S}$ et al. Directed duct excision by using mammary ductoscopy in patients with pathologic nipple discharge. Surgery 2002; 132:582-587.

69. Cardenosa G, Eklund GW. Benign papillary neoplasms of the breast: mammographic findings. Radiology 1991; 181:751-755.

70. Ali-Fehmi R, Carolin K, Wallis $\mathrm{T}$ et al. Clinicopathologic analysis of breast lesions associated with multiple papillomas. Hum Pathol 2003; 34:234-239.

71. Page DL, Salhany KE, Jensen RA et al. Subsequent breast carcinoma risk after biopsy with atypia in a breast papilloma. Cancer 1996; 78:258-266.

72. O'Malley F, Visscher D, MacGrogan G et al. Intraductal papillary lesions. In: Lakhani SR, Ellis $\mathrm{IO}$, Schnitt SJ et al (eds) WHO classification of tumors of the breast, 4th edn. International Agency for Research on Cancer, Lyon, 2012; pp 99-109.

73. Cserni G. The current TNM classification of breast carcinomas: controversial issues in early breast cancer. memo Magazine of European Medical Oncology 2011; 4:144-148.

74. Sakr R, Rouzier R, Salem C et al. Risk of breast cancer associated with papilloma. EJSO 2008; 34:1304-1308.

75. El-Sayed ME, Rakha EA, Reed J et al. Predictive value of needle core biopsy diagnoses of lesions of uncertain malignant potential $(\mathrm{B}+)$ in abnormalities detected by mammographic screening. Hystopathology 2008; 53:650-657.

76. Hultborn KA, Larsson LG, Ragnhult I. The lymph drainage from the breast to the axillary and parasternal lymph nodes, studied with the aid of colloidal AU198. Acta Radiol 1955; 43:52-64.

77. Turner-Warwick RT. The lymphatics of the breast. Br J Surg 1959; 46:574-582.

78. Nathan J, Boyages J, French JR et al. Internal mammary sentinel nodes: ignore, irradiate or operate? Eur J Cancer 2008; 45:789-794.

79. Veronesi U, Cascinelli N, Greco M et al. Prognosis of breast cancer patients after mastectomy and dissection of internal mammary nodes. Ann Surg 1985; 202:702-707.

80. Madsen E, Gobardhan PD, Bongers V et al. The impact on post-surgical treatment of sentinel lymph node biopsy of internal mammary lymph nodes in patients with breast cancer. Ann Surg Oncol 2007; 14:1486-1492.

81. Roumen RMH, Geuskens LM, Valkenburg JGH et al. In search of the true sentinel node by different injection techniques in breast cancer patients. Eur J Surg Oncol 1999; 25:347-351.

82. Borgstein PJ, Meijer S, Pijpers RJ et al. Functional lymphatic anatomy for sentinel node biopsy in breast cancer: echoes from the past and the periareolar blue method. Ann Surg 2000; 1: 81-89.

83. Spillane AJ, Noush IF, Cooper RA et al. High resolution lymphoscintigraphy is essential for recognition of the significance of internal mammary nodes in breast cancer. Ann Oncol 2009; 20:977984.

84. Sugg SL, Ferguson DJ, Posner MC et al. Should internal mammary nodes be sampled in the sentinel lymph node era? Ann Surg Oncol 2000; 7:188-192

85. Van der Ent FW, Kengen RA, van der Pol HA et al. Halsted revisited: internal mammary sentinel lymph node biopsy in breast cancer. Ann Surg 2001; 234:79-84.

86. Overgaard $\mathrm{M}$, Jensen $\mathrm{MB}$, Overgaard $\mathrm{J}$ et al. Postoperative radiotherapy in high-risk postmenopausal breast-cancer patients given adjuvant tamoxifen: Danish Breast Cancer Cooperative Group DBCG 82c randomised trial. Lancet 1999; 353:1641-1648.

87. Ragaz J, Jackson SM, Le $\mathrm{N}$ et al. Adjuvant radiotherapy and chemotherapy in node-positive premenopausal women with breast cancer. N Engl J Med 1997; 337:956-962.

88. Whelan TJ, Julian J, Wright J et al. Does locoregional radiation therapy improve survival in breast cancer? A meta-analysis. J Clin Oncol 2000; 18:1220-1229.

89. Obedian E, Hafty BG. Internal mammary nodal irradiation in conservatively managed breast cancer patients: is there a benefit? Int J Radiat Oncol Biol Phys 1999; 44: 997-1003.

90. Freedman GM, Fowble BL, Nicolaou N et al. Should internal mammary lymph nodes in breast cancer be the target for the radiation oncologist? Int J Radiat Oncol Biol Phys 46:805-814.

91. Jatoi I. Internal mammary sentinel nodes in primary breast cancer. Curr Med Res Opin 2003; 19:567-569. 
92. Fowble B, Hanlon A, Freedman G et al. Internal mammary node irradiation neither decreases distant metastases nor improves survival in stage I and II breast cancer. Int J Radiat Oncol Biol Phys 2000; 47:883-894.

93. Matzinger O, Heimsoth I, Poortmans $\mathrm{P}$ et al. Toxicity at three years with and without irradiation of the internal mammary and medial supraclavicular lymph node chain in stage I to III breast cancer (EORTC trial 22922/10925) Act. Oncol 2010; 49:24-34.

94. Clarke M, Collins R, Darby S et al. Effects of radiotherapy and of differences in the extent of surgery for early breast cancer on local recurrence and 15-year survival: an overview of the randomised trials. Lancet 2005; 366: 2087-2106.

95. Early Breast Cancer Trialists' Collaborative Group (EBCTGC) Effects of chemotherapy and hormonal therapy for early breast cancer: effects on recurrence and 15-year survival: an overview of the randomised trials. Lancet $2005 ; 365: 1687-1717$.

96. Dutch national guideline for the treatment of breast cancer, version 2.0 (Feb2012) http://www.oncoline.nl/mammacarcinoom. Accessed 22 Feb 2012

97. Heuts EM, van der Ent FW, Hulsewe KWE et al. Results of tailored treatment for breast cancer patients with internal mammary lymph node metastases. The Breast 2009; 18:254-258.

98. Postma EL, van Wieringen S, Hobbelink MG et al. Sentinel lymph node biopsy of the internal mammary chain in breast cancer. Breast Cancer Res Treat 2012; 134:735-774.

99. Leidenius MHK, Krogerud LA, Toivonen TS et al. The clinical value of parasternal sentinel node biopsy in breast cancer. Ann Surg Oncol 2006; 13: 321-326.

100. Coombs NJ, Boyages J, French JR et al. Internal mammary sentinel nodes: ignore, irradiate or operate? Eur J Cancer 2009; 45:789-794.

101. Cserni G. What is a positive sentinel lymph node in a breast cancer patient? A practical approach. Breast 2007; 16:152-160

102. Kiluk JV, Lee MC, Park CK et al. Male breast cancer: management and follow-up recommendations. Breast J 2011; 17:503-509.

103. Giuliano AE, Dale PS, Turner RR et al. Improved axillary staging of breast cancer with sentinel lymphadenectomy. Ann Surg 1995; 222:394-399 (discussion 399-401).

104. Luci A, Mackie L, Beitsch PD et al. Surgical complications associated with sentinel lymph node dissection (SLND) plus axillary lymph node dissection, versus SLND alone in The American College of Surgeons Oncology Group (ACOSOG) Trial Z0011. Ann Surg Oncol 2006; 13 [2 Suppl]:4. 22.

105. Peintinger F, Reitsamer R, Stranzl $\mathrm{H}$ et al. Comparison of quality of life and arm complaints after axillary lymph node dissection vs sentinel lymph node biopsy in breast cancer patients. $\mathrm{Br} \mathrm{J}$ Cancer 2003; 89:648-652.

106. Schijven MP, Vingerhoets AJ, Rutten HJ et al. Comparison of morbidity between axillary lymph node dissection and sentinel node biopsy. Eur J Surg Oncol 2003; 29:341-350.

107. Golshan M, Martin WJ, Dowlatshahi K. Sentinel lymph node biopsy lowers the rate of lymphedema when compared with standard axillary lymph node dissection. Am Surg 2003; 69: 209211 (discussion 212).

108. Schrenk P, Rieger R, Shamiyeh A et al. Morbidity following sentinel lymph node biopsy versus axillary lymph node dissection for patients with breast carcinoma. Cancer 2000; 88: 608-614.

109. Veronesi U, Paganelli G, Viale G et al. A randomized comparison of sentinel-node biopsy with routine axillary dissection in breast cancer. $N$ Engl J Med 2003; 349:546-53.

110. Fleissig A, Fallowfield LJ, Langridge CI et al. Post-operative arm morbidity and quality of life.

Results of the ALMANAC randomised trial comparing sentinel node biopsy with standard axillary treatment in the management of patients with early breast cancer. Breast Cancer Res Treat 2006; 95:279-293.

111. Boughey JC, Bedrosian I, Meric-Bernstam F et al. Comparative analysis of sentinel lymph node operation in male and female breast cancer patients. J Am Coll Surg 2006; 203:475-80.

112. Lyman GH, Giuliano AE, Somerfield MR et al. American Society of Clinical Oncology guideline recommendations for sentinel lymph node biopsy in early-stage breast cancer. J Clin Oncol 2005; 23: $7703-7720$. 
113. Tew K, Irwiq L, Matthews A et al. Meta-analysis of sentinel node imprint cytology in breast cancer. Br J Surg 2005; 92:1068-1080.

114. Cserni G, Amendoeira I, Apostolikas $\mathrm{N}$ et al. Pathological workup of sentinel lymph nodes in breast cancer. Review of current data to be considered for the formulation of guidelines. Eur J Cancer 2003; 39:1654-1667.

115. Liu LC, Lang JE, Lu Y et al. Intraoperative frozen section analysis of sentinel lymph nodes in breast cancer patients. Cancer 2011; 117:250-258.

116. Cserni G. Intraoperative analysis of sentinel lymph nodes in breast cancer by one-step nucleic acid amplification (OSNA). J Clin Pathol 2012; 65:193-199.

117. Flynn LW, Park J, Patil SM et al. Sentinel lymph node biopsy is successful and accurate in male breast carcinoma. J Am Coll Surg 2008; 206:616-621.

118. Rusby JE, Smith BL, Dominguez FJ et al. Sentinel lymph node biopsy in men breast cancer: a report of 31 consecutive procedures and review of the literature. Clin Breast Cancer 2006; 7:406-410.

119. Gentilini O, Chagas E, Zurrida $S$ et al. Sentinel lymph node biopsy in male patients with early breast cancer. Oncologist 2007; 12:512-515.

120. Cserni G, Gregori D, Merletti F et al. Meta-analysis of non-sentinel node metastases associated with micrometastatic sentinel nodes in breast cancer. Br J Surg 2004; 91:1245-1252.

121. van Deurzen $\mathrm{CH}$, de Boer M, Monninkhof EM et al. Non-sentinel lymph node metastases associated with isolated breast cancer cells in the sentinel node. J Natl Cancer Inst 2008;100:15741580 .

122. De Mascarel I, MacGrogan G, Debled M et al. Distinction between isolated tumor cells and micrometastases in breast cancer: is it reliable and useful? Cancer 2008; 112:1672-1678.

123. Cserni G, Bianchi S, Vezzosi V et al. Variations in sentinel node isolated tumor cells / micrometastasis and non-sentinel node involvement rates according to different interpretations of the TNM definitions. Eur J Cancer 2008; 44:2185-2191.

124. Cserni G, Bezsenyi I, Marko L. Patients' choice on axillary lymph node dissection following sentinel lymph node micrometastasis--first report on prospective use of a nomogram in very low risk patients. Pathol Oncol Res 2013; 19: 211-216.

125. Meretoja TJ, Vironen JH, Heikkila PS et al. Outcome of selected breast cancer patients with micrometastasis or isolated tumor cells in sentinel node biopsy and no completion axillary lymph node dissection. J Surg Oncol 2010; 102: 215-219.

126. Lázár G, Besznyák I, Boross G et al (2010) Az emlőrák korszerü sebészi kezelése. M Onkol 2010; 54:227-236. 
9. APPENDIX 
I. 
II. 
III. 
IV. 